اثر تعديل كنندگى يرايمينگ بذر بر تغيير برخى صفات مورفولوزيك، تغييرات يونهاى معدنى، عملكرد و اجزاى عملكرد رقم آرمان نخود تحت شورى آب آبيارى

على غلامىزالى'، يعقوب خانى كريمآبادى'، برويز احسانزاده־” وجمشيد رزمجو׳

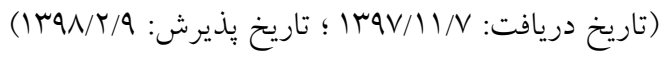

جكيده

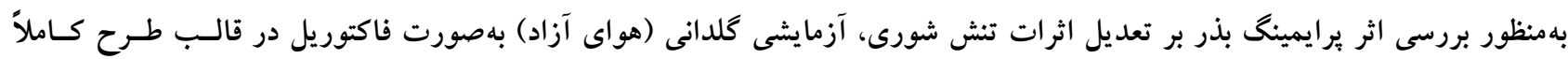

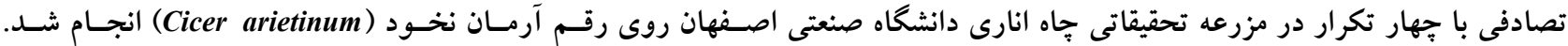

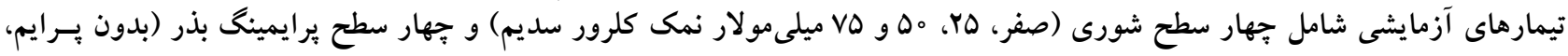

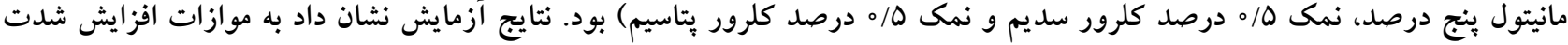

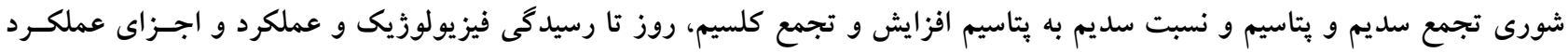

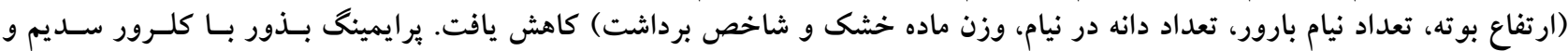

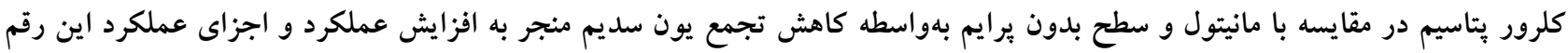

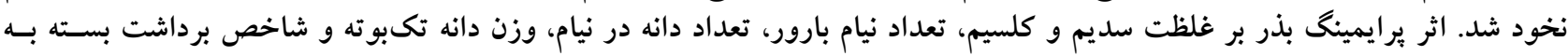

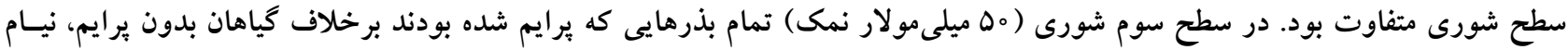

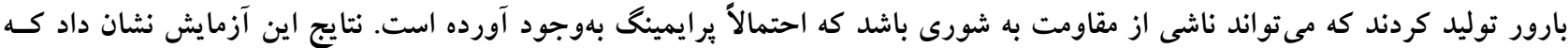

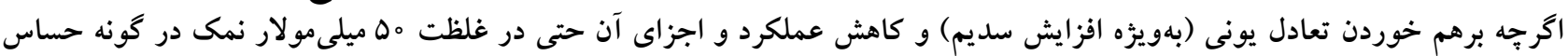

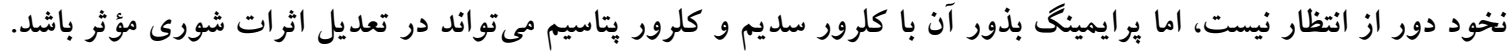

وازههاى كليدى: اسموير ايمينگ (كلرور سديم و يتاسيم)، هالويرايمينگ (مانيتول)، وزن دانه تكبوته

ا و r. بهترتيب دانشجويان كارشناسى ارشد و استادان كروه زراعت و اصلاح نباتات، دانشكده كشاورزى، دانشكاه صنعتى اصفهان، اصفهان، ايران

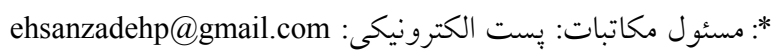


بر متر) در كياه نخود كاهش ارتفاع بوتـه، تعـداد نيـام در بوتسه،

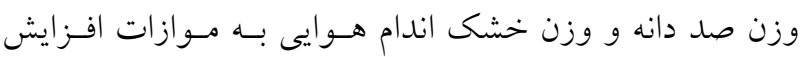

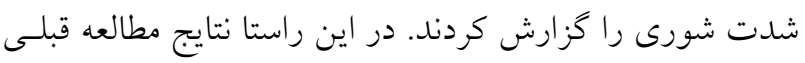

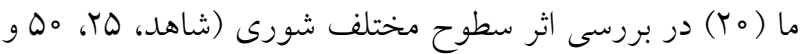

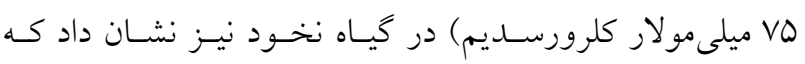

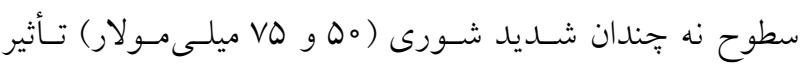
جشمخيرى در كاهش عملكرد و اجزاى عملكرد نخود دارد.

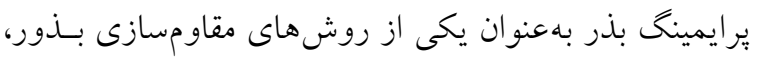
بهبود رشــ كياهجهـهــا و شـاخصهـاى بنيـه بـــر در مرحلـه. جوانهزنى و رشد اوليه در برابر تنش تنش شورى مطـرح اسـت

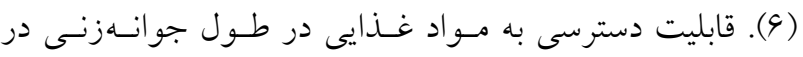
بذرهاى يرايم شده آسانتر است و اين بذرها بهتر قادر به كامـل

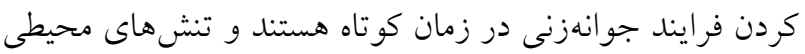

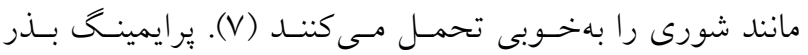

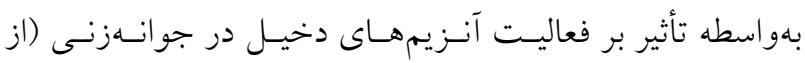

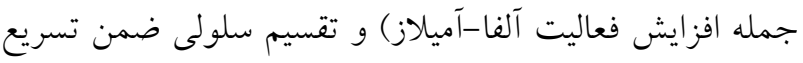

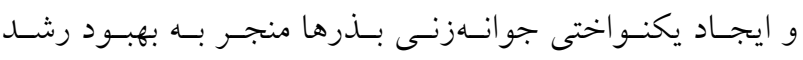

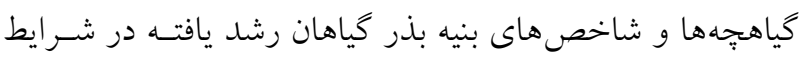

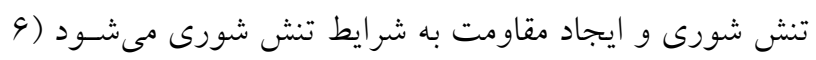

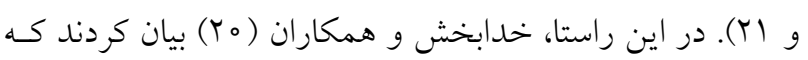

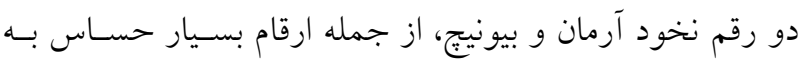

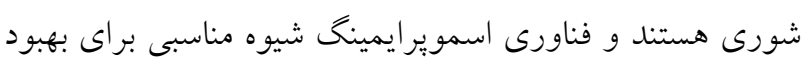

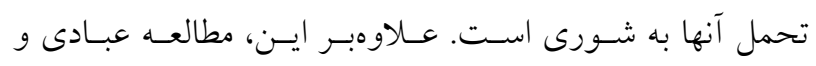

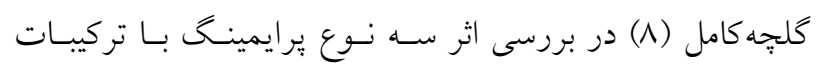

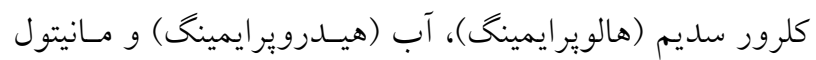

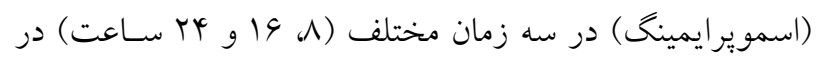

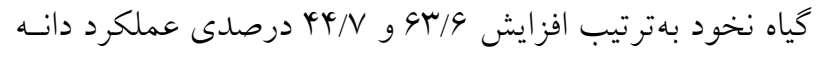

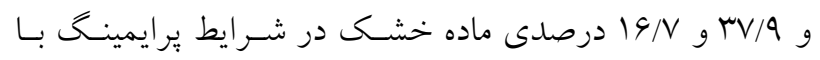

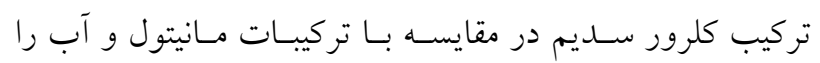
نشان داد كه بيانكر مؤثر بودن تركيبـات هالويرايمينـ (كلـرور

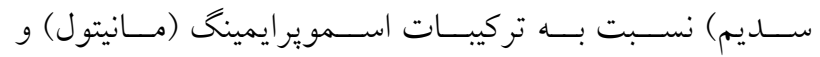

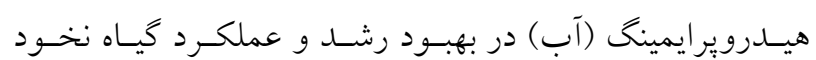

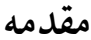

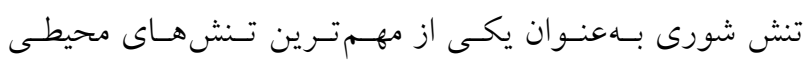

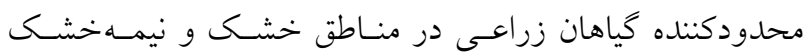

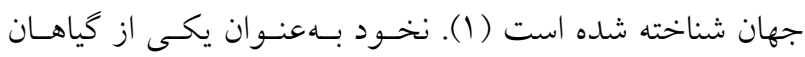

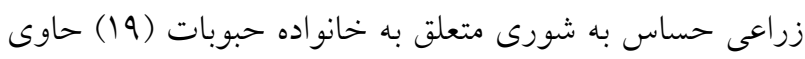

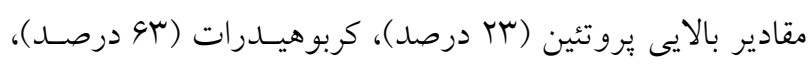

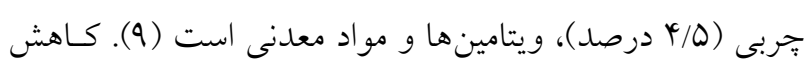

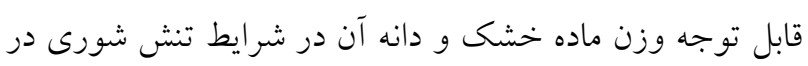

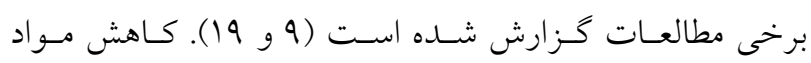

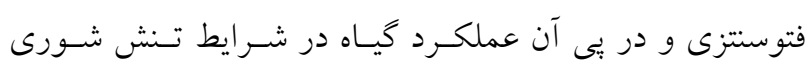

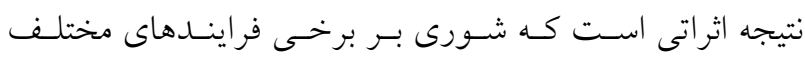

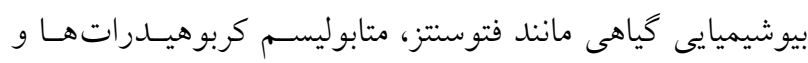

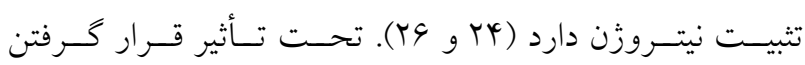

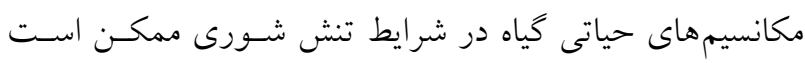
ناشى از تنش خشكى حاصل از افزايش فشار اسمزى و كـاهش

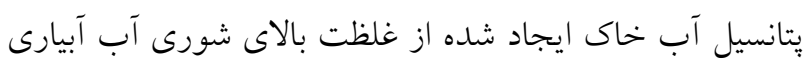

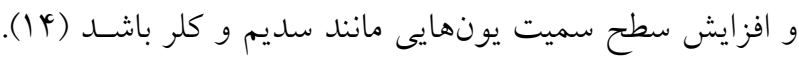

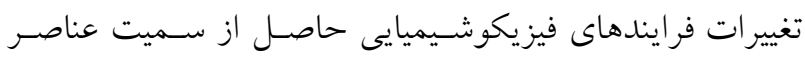
حاصل از تنش شورى (سديم و كلر) بهصورت كلروز و نكسروز شدن سطح سبز در كيـاه بديــار مسى شـود ( (1). در ايسن راسـتا،

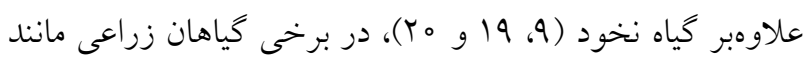

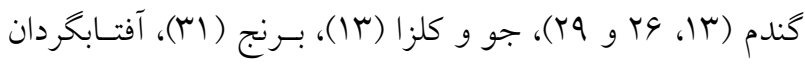

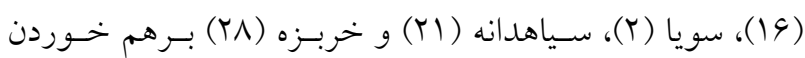
تعادل يونى، كاهش غلظت رنخيزههاى فتوسنتزى و به تبـع آنها

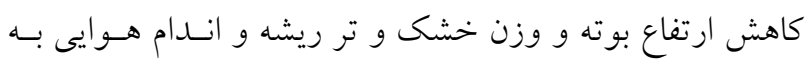

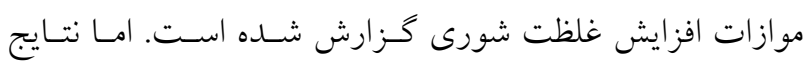

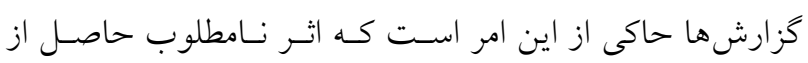

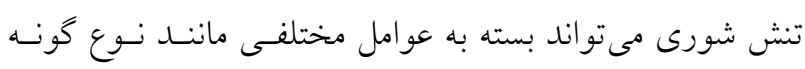

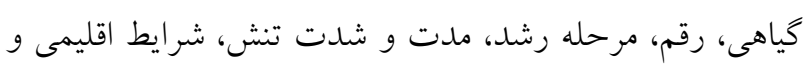

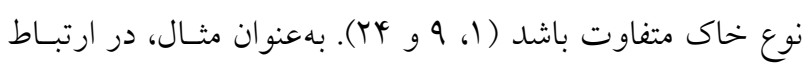
با اثرات افزايش شدت تنش شورى، ابتهـال و همكـاران (9) در

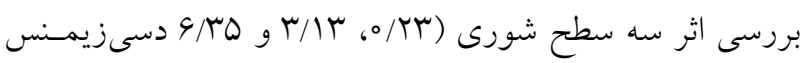


جدول ا. برخى ويزگى هاى فيزيكوشيميايى خاى مورد استفاده در كلدانها

\begin{tabular}{|c|c|c|c|c|c|}
\hline \multirow{2}{*}{$\mathrm{pH}$} & هدايت الكتريكى & \multirow{2}{*}{ بافت } & سيلت & شن & رس \\
\hline & (دسىزيمنس بر متر) & & \multicolumn{3}{|c|}{ (درصد) } \\
\hline$V / D$ & 1 & سيلتى لوم & س & $r G / r$ & $Y Y / Y$ \\
\hline
\end{tabular}

آرمان نخود انجام شد. جهار سطح شـورى آب آبيـارى (صـفر،

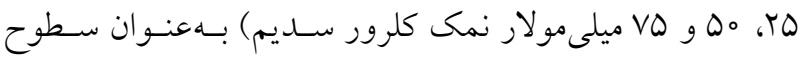

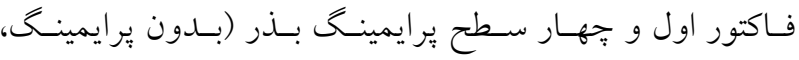

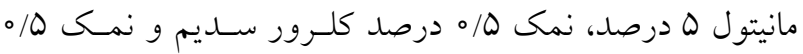

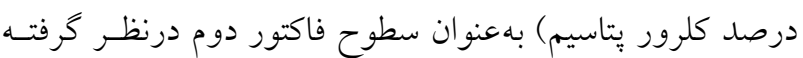

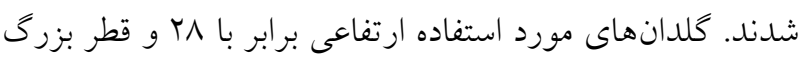

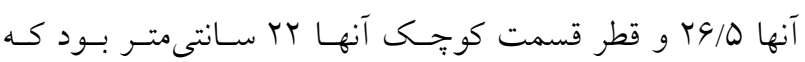

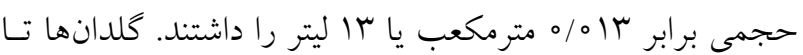

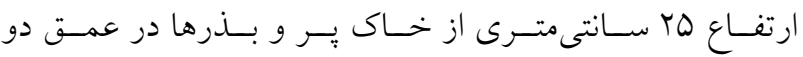
سانتى مترى كاشت شدند. برخسى ويزگكى هـاى فيزيكوشسيميايى

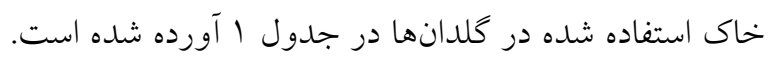

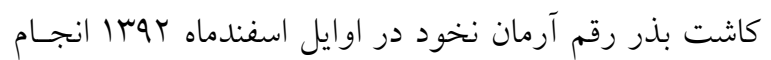

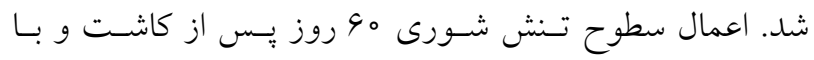

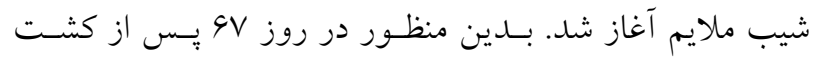

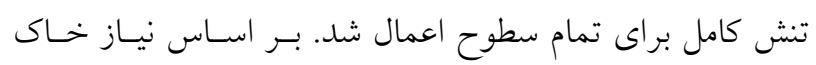

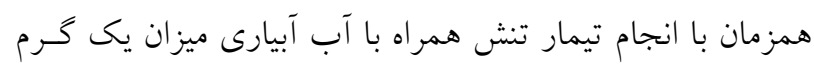

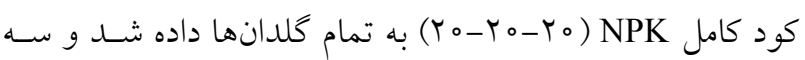

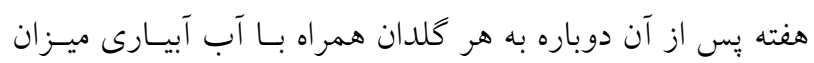
يك گرم كود كامل داده شد.

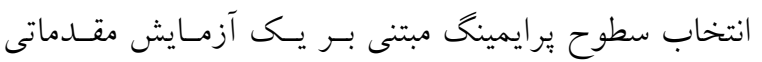
جوانهزنسى بـا ب F تيمـار در قالـب طـرح كـاملاً تصـادفى بـوده.

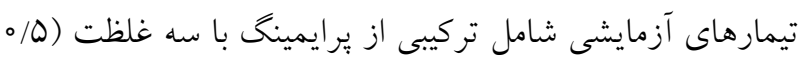

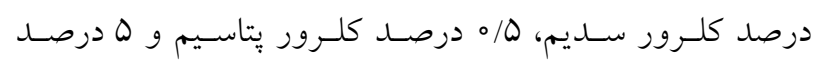

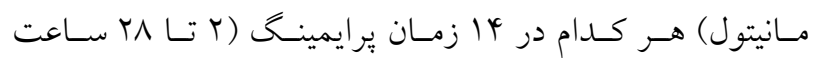
ير ايمينگ) با سه تكرار بود (غلظتهاى انتخاب شــده تركيبـات

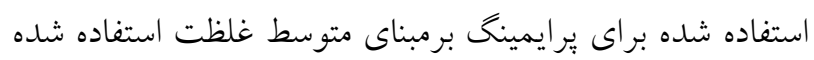

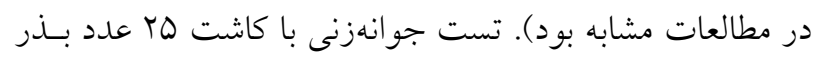
نخود در يترىديشهاى با قطر ها سانتىمتر در داخل زرميناتور

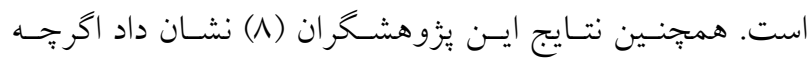

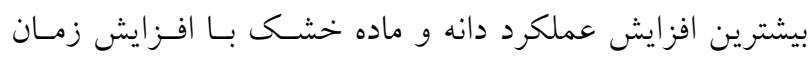

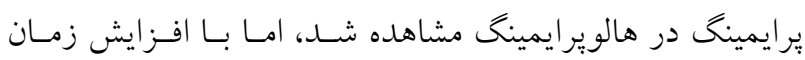

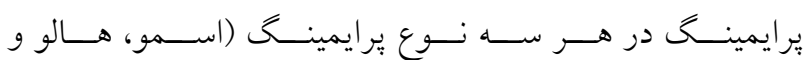

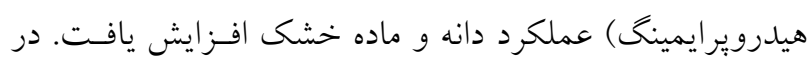

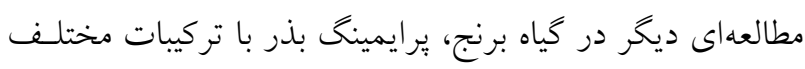

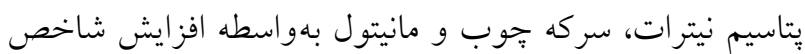
پايدارى، غلظت كلروفيل و كاهش نسبت سديم به به بتاسيم منجر به افزايش وزن ماده خشك در شرايط تــش شـورى شـــ (آم). علاوهبر اين، مطالعه قاسمى كلعذانى (11) در كياه عــس نشـان

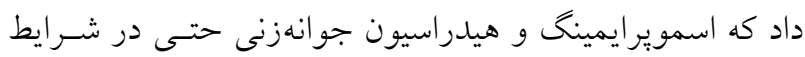
غير شور، درصد جوانهزنى را بهبود ميدهد. حسين و همكـاران

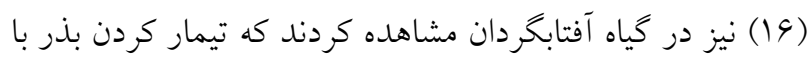

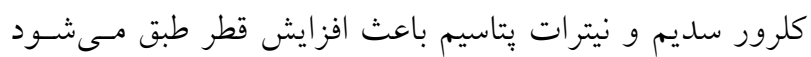

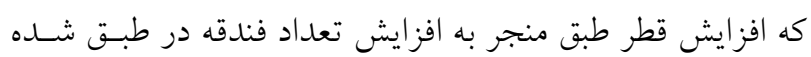

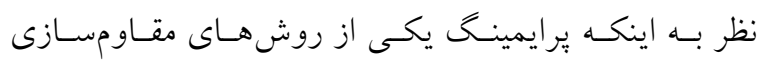

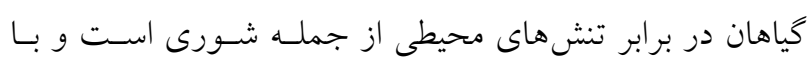

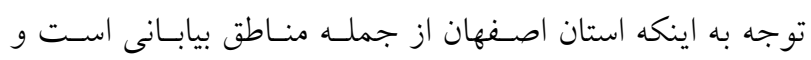
خاك و آب آن يا شور و يا مستعد شور شدن هستند و مطالعات آنسات

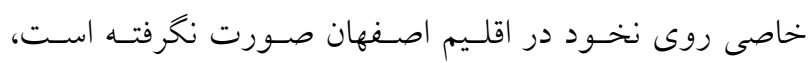

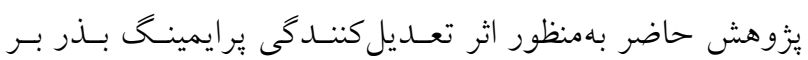

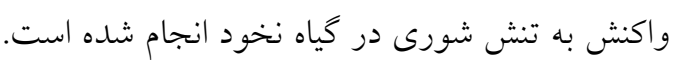

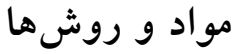

اين يزوهش در بهار بهوا در آزمايشى كلداني (در هــواى آزاد)

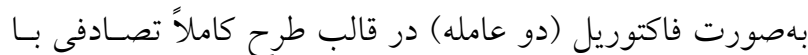
جهار تكرار در مزرعه جــاه انـارى دانشـاه صـنعتى روى رقـم 
ظرفيت زراعى رسيدند. در سطح دوم شـورى (TO ميلسى مـولار)

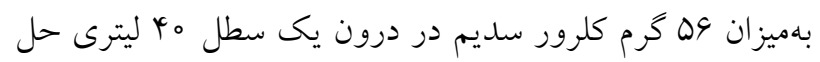

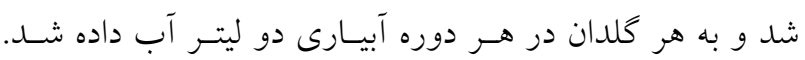

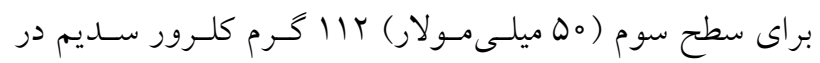

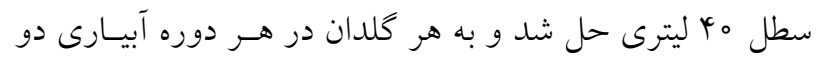

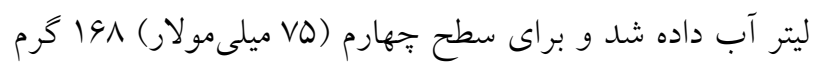

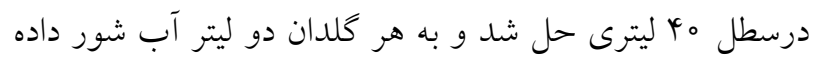

در طول آزمايش برخى صفات فنولوزيكى و ريختشناسى

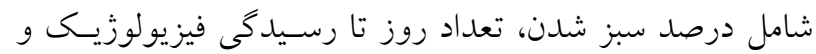

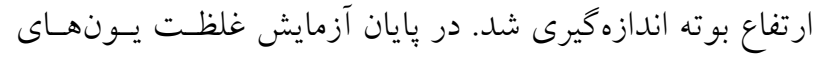

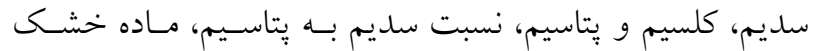

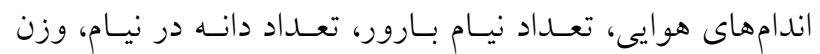

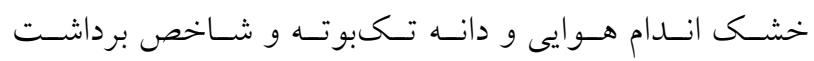

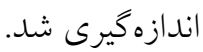

اندازهيرى غلظت يـونهــاى ســـيم، يتاســم و كلسـيم در

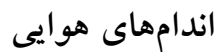
براى اين كار از روش خاكستركيرى خشك استفاده شـــ. در بايـان

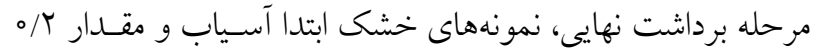

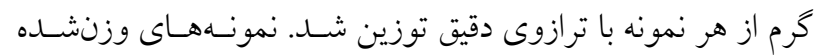

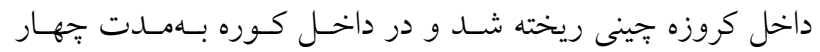

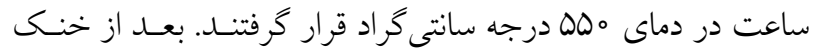

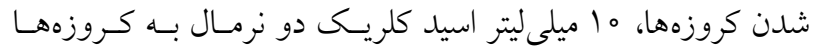
اضافه شد. سبس بــا حـرارت دادن ملايــم كـروزه روى هيتـر مـواد

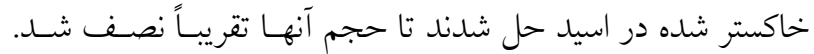

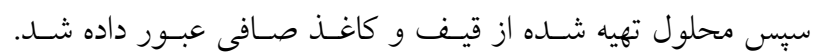

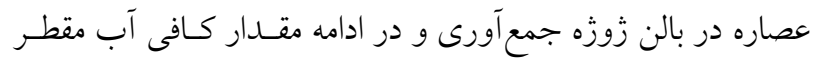

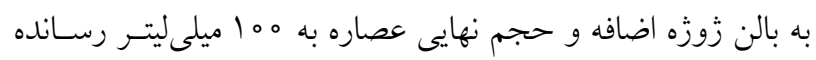

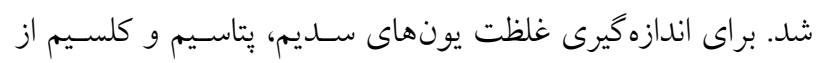

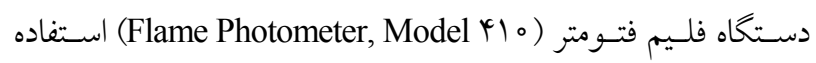

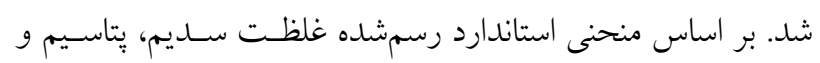

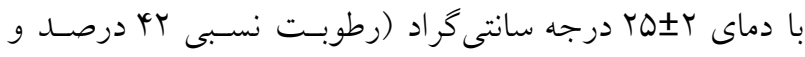

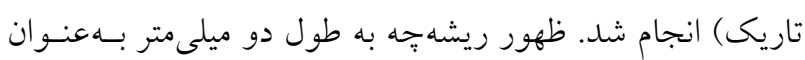
بذر جوانهزده تلقى و در پِايان روز هفتم بـــرهاى جوانسهزده در

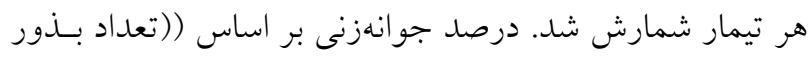

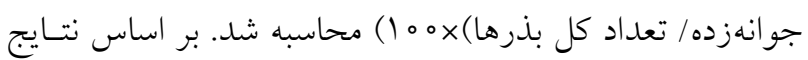

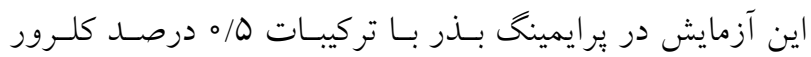
سديم و كلرور يتاسيم بعد از †| ساعت و در تركيـب ه درصـد

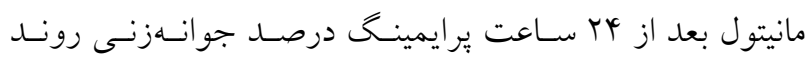
كاهشى در درصد جوانهزنى راشروع كرد (قبل از اين زمـانهـا

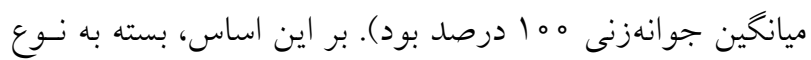

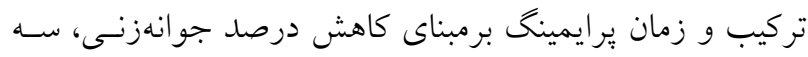
تركيـب تيمـارى (ه/ه، ه/ و ه درصــ كلـرور ســيم، كلـرور

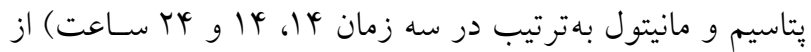

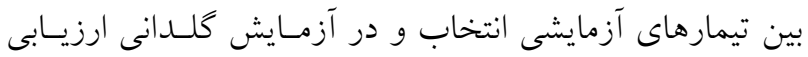

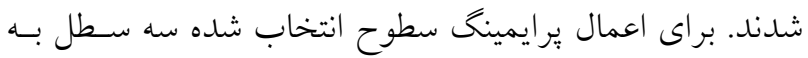

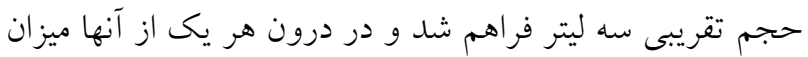

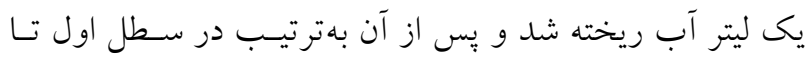

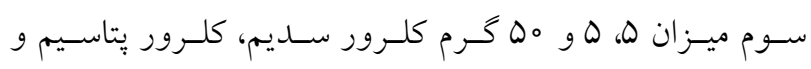

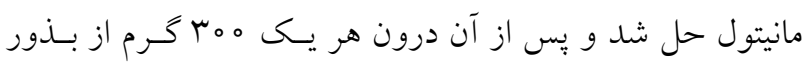

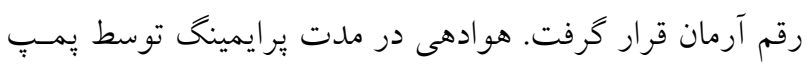

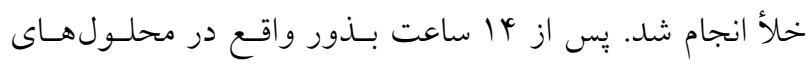

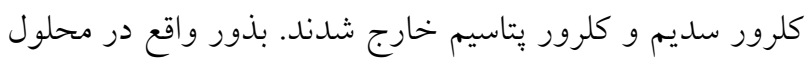

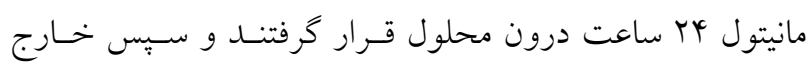

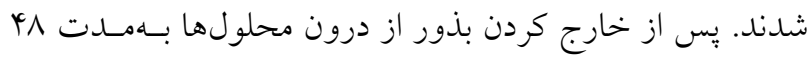

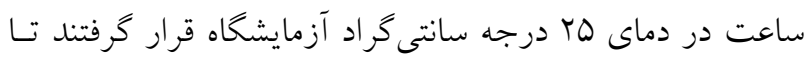

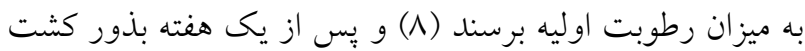

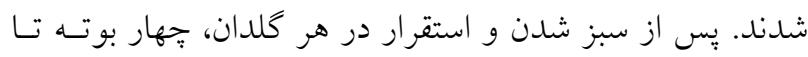

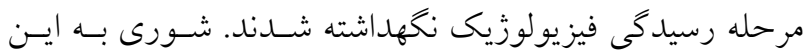
صورت اعمال شد كه هو روز بّ از كاشت كلدانها بـه جهـار

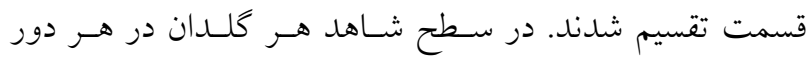

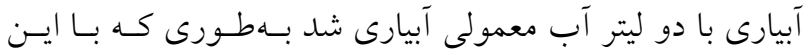

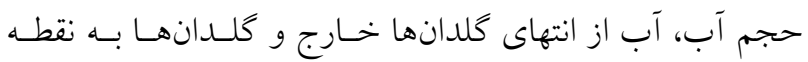


پِاسيم و كلسيم، نسبت سديم به بتاسـيم انـام هـوايى، روز تـا

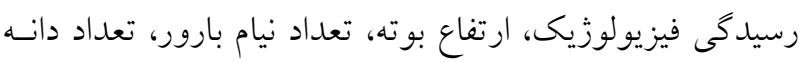

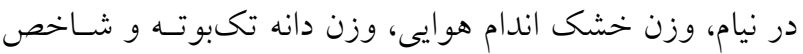

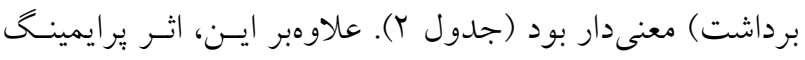

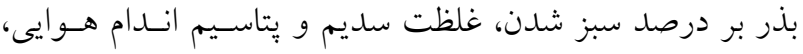

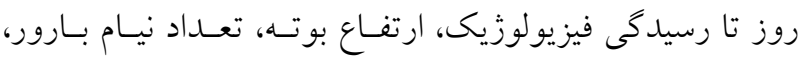

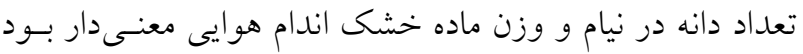
(جدول Y). اثر متقابل شورى در بر ايمينخ فقط بر غلظت سديم و كلسيم اندام هوايى، تعداد نيام بارور، تعداد دانه در نيـام، وزن دانه تكبوته و شاخص برداشت معنىدار بود (جدول Y).

\section{صفات فنولوزيك، ريختشناسى و غلظت يونهاى معدنى}

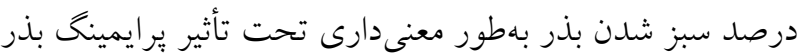

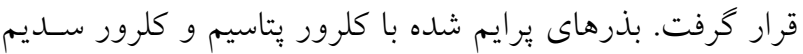

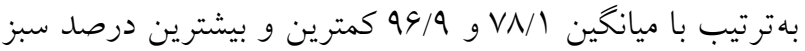

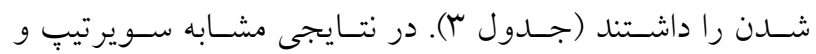
همكاران (YN) در مطالعهاى در ارتباط با يرايمينخ بذر با كلرور

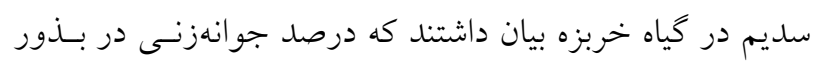

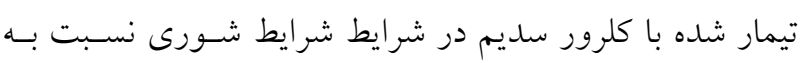

$$
\text { بذور برايم نشده افزايش مىيابد. }
$$

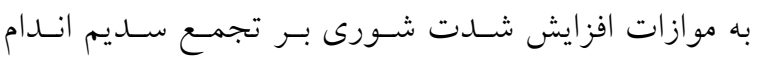

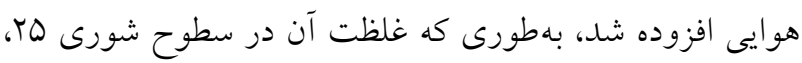

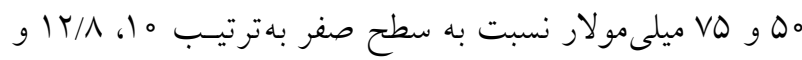

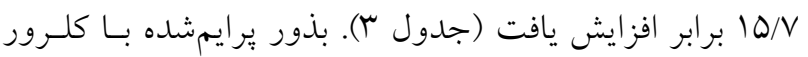

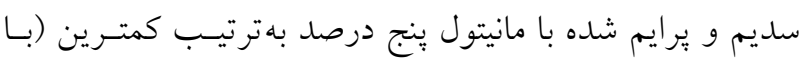

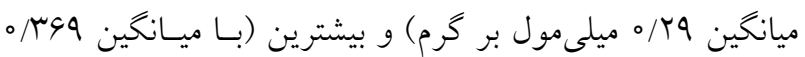

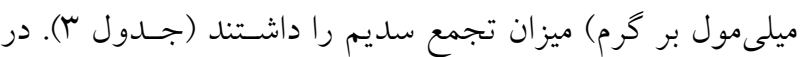

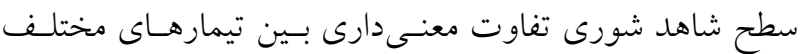

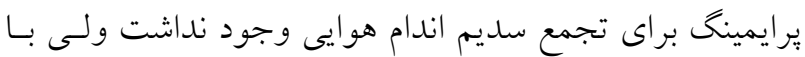

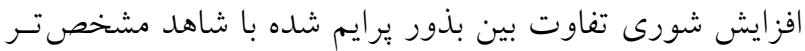

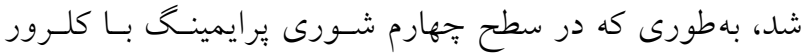
سديم و كلرور يتاسيم كمترين ميزان تجمع سديم (بهترتيـب بـا

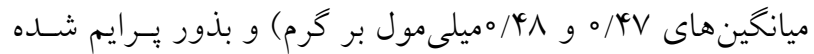

كلسيم نمونه گياهى برحسب ميلى گرم بر گرم با قرار دادن در رابطـه.

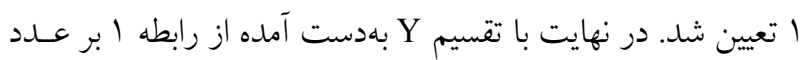

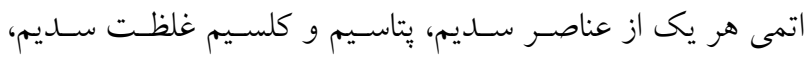

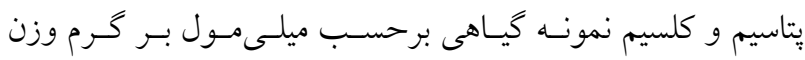

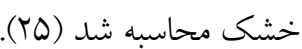

$\mathrm{Y}=\frac{\mathrm{X}-\circ / 1}{\mathrm{~W}}$

در رابطه بالا Xيانكر غلظت سديم، بتاسيم و كلسيم در نمونه كيـاهى

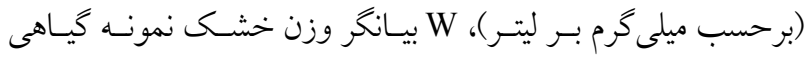

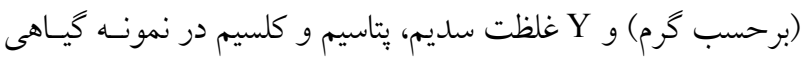
(برحسب ميلى گرم بر گرم وزن خشك نمونه) را نشان مىدهد.

عملكرد دانه و اجزاى عملكرد يس از برداشت تعداد نيامهـايى بــارور و تعـداد دانـه در نيـام در

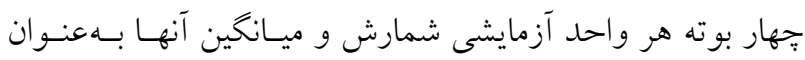

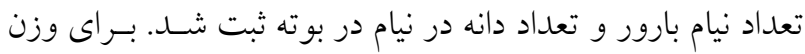

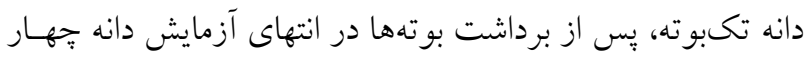

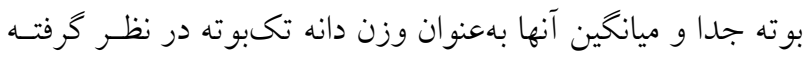

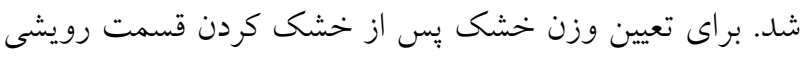

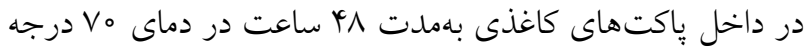

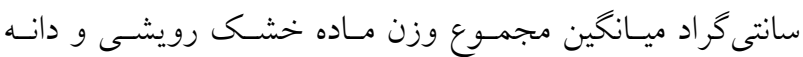
به عنوان وزن خشك ماده خشك انــام هـوايى تـكبوتـه در نظـر كرفته شد. شاخص برداشت از تقسيم وزن دانه (تكبوته) بر وزن خشك ماده اندام هو ايى (تكبوته) محاسبه شد.

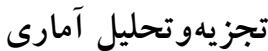

دادهها با استفاده از نرمافزار SAS (نسخه ك/T) تجزيسه آمـارى و و ميانخين ها با آزمون حـدقل تفـاوت معنىدار (LSD) در سـطح احتمال بينج درصد مقايسه شدند.

\section{نتايج و بحث}

نتايج تجزيه واريانس نشان داد كه اثر تسنش شـورى بـر تمـامى لــ صفات مورد مطالعه (درصد سبز شدن، غلظت يونهاى سـديم، 


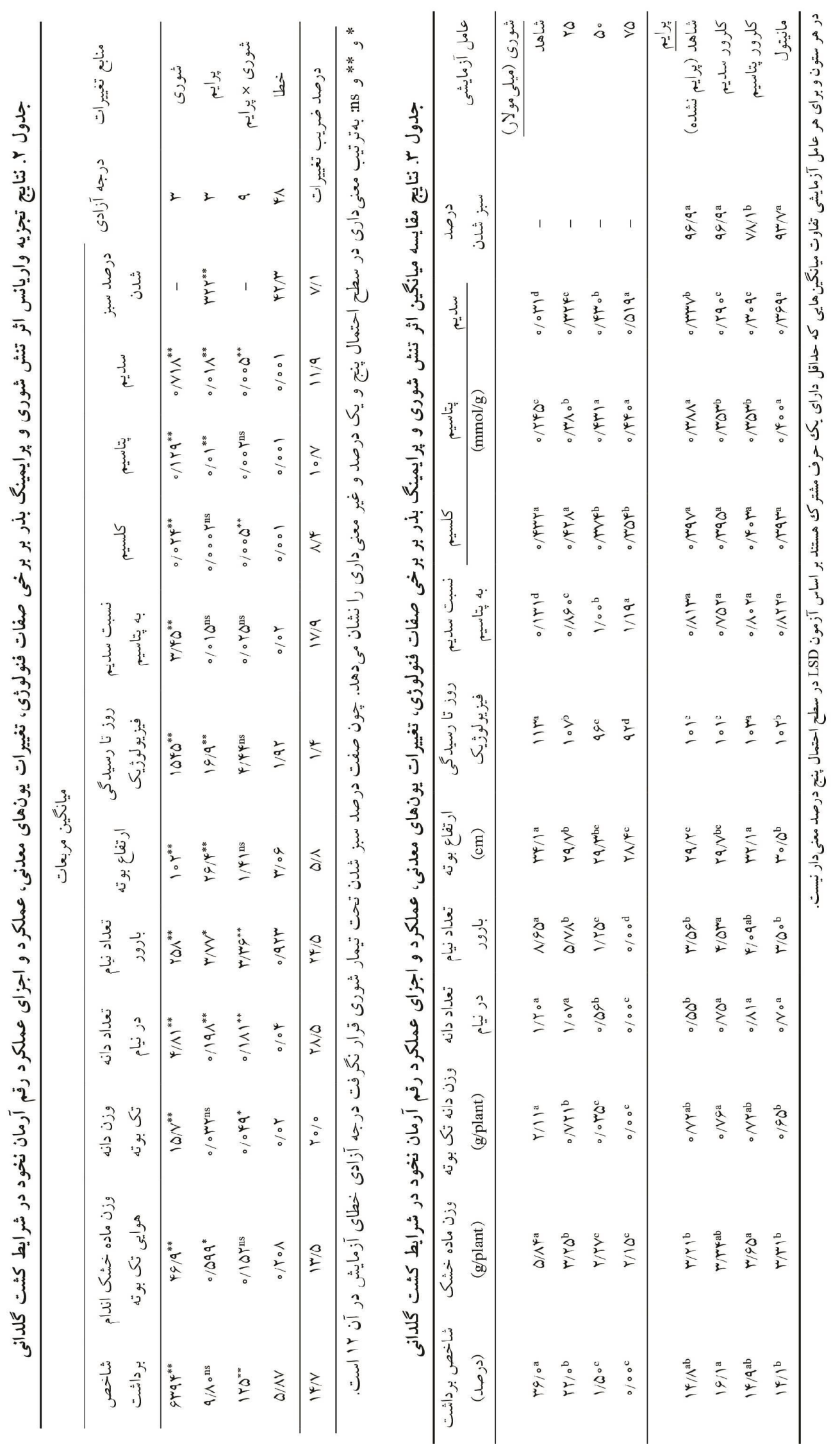


جدول f. ميانگين اثرات متقابل صفات غلظت سديم و كلسيم، تعداد نيام بارور، تعداد دانه در نيام، عملكرد دانه، شاخص برداشت، رقم

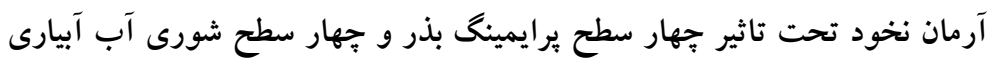

\begin{tabular}{|c|c|c|c|c|c|c|c|}
\hline شاخص & وزن دانه تكبو & \multirow[t]{2}{*}{ تعداد دانه در نيام } & \multirow{2}{*}{ تعداد نيام بارور } & كلسيم & سديم & \multirow{2}{*}{ يرايم } & شورى \\
\hline ) & (g/plant) & & & \multicolumn{2}{|c|}{$(\mathrm{mmol} / \mathrm{g})$} & & (ميلى مولار) \\
\hline$r q^{a}$ & $r / \Gamma)^{a}$ & $1 / 10^{a}$ & $9 / 1 r^{a}$ & $0 / 4 Y^{a b c}$ & $\circ / \circ \mu^{f} f$ & شاهد (يرايم نشده) & \\
\hline$r_{\wedge^{\mathrm{a}}}$ & $r / Y \circ a b$ & $1 / 1 \wedge^{\mathrm{a}}$ & $10 / 4^{a}$ & $0 / 44^{a}$ & o/orrf & كلرور سديم & شاهد \\
\hline ( & $r / \circ V^{b}$ & $1 / r \Delta^{a}$ & $V / 9 Y^{b}$ & $\circ / q b c d$ & $\circ / \circ l^{f}$ & كلرور يتاسيم & (صفر) \\
\hline ryb & $1 / A V^{c}$ & $1 / r r^{a}$ & $V / D \circ b c$ & $\circ / 4 \Delta^{a}$ & $0 / 0 r r_{f}^{f}$ & مانيتول & \\
\hline rod &.$/ 09^{d}$ & $1 / \circ V^{a}$ & $\Delta / 1 r^{d}$ & $\circ / 4$ rab & $\circ / r r^{d e}$ & شاهد (يرايم نشده) & \\
\hline$r \mu^{c}$ & $\circ / V q^{d}$ & $1 / \circ 9^{a}$ & $q / r Q^{\mathrm{cd}}$ & $0 / 4 Y^{a b c}$ & $0 / Y q^{e}$ & كلرور سديم & ro \\
\hline$r^{\mathrm{c}}$ & $\circ / V \varphi^{d}$ & $1 / 01^{a b}$ & $9100^{d}$ & $0 / 4 r a b$ & $\circ / r r^{d e}$ & كلرور يتاسيم & 10 \\
\hline$r Y^{\mathrm{cd}}$ & $\circ / V r^{d}$ & $1 / 1 \circ a$ & $\Delta / V \Delta^{d}$ & $0 / 4 Y a b c$ & $\circ / r y \mathrm{de}$ & مانيتول & \\
\hline$\circ / \circ \circ \mathrm{e}$ & $\circ / \circ \circ$ & o/od & $\circ / \circ \circ \mathrm{g}$ & $\circ / \pi \Delta^{e f}$ & $0 / 4 y c$ & شاهد (برايم نشده) & \\
\hline$r / r^{\mathrm{e}}$ & $\circ / 0 y_{0} \mathrm{e}$ & $\circ / V \Delta^{b c}$ & $1 / 0 \circ \mathrm{ef}$ & $0 / \mu r^{f}$ & $\circ /$ red & كلرور سديم & Q0 \\
\hline$r / l^{e}$ & $\circ / \circ V Q^{e}$ & $1 / \circ \circ a b$ & $r / V Q^{e}$ & $\circ / 4 \Delta^{a}$ & $\circ / \pi V^{d}$ & كلرور يتاسيم & \\
\hline $1 / 0 \mathrm{e}$ & $\circ / \circ Y_{\circ} \mathrm{e}$ & $\circ / 0 \circ c$ & $\circ / V \Delta^{\mathrm{fg}}$ & $\circ / r \Delta^{d e f}$ & $\circ / \Delta r^{a b}$ & مانيتول & \\
\hline$\circ / \circ 0^{e}$ & $\circ / 00^{\circ}$ & $\circ / 0 o^{d}$ & $\circ / \circ \circ \mathrm{g}$ & $\circ / \mu^{c d e}$ & $\circ / \Delta \Delta^{a}$ & شاهد (يرايم نشده) & \\
\hline$\circ / 0 \circ \mathrm{e}$ & $\circ / \circ \circ$ & $\circ / 0^{d}$ & $\circ / 0 \circ g$ & $\circ / r \varphi \operatorname{def}$ & $\circ / 4 V^{c}$ & كلرور سديم & VD \\
\hline$\circ / 0 \circ e$ & $\circ / 0 \circ$ & $\circ / 00^{d}$ & $\circ / \circ \circ g$ & $0 / \mu r^{f}$ & $\circ / 4 \wedge^{b c}$ & كلرور پيتاسيم & $v_{\omega}$ \\
\hline $0 / 00^{e}$ & $\% 0^{\mathrm{e}}$ & $\% / 0^{d}$ & $\circ / 0 \circ \mathrm{g}$ & $\circ /$ ryef &.$/ 09^{a}$ & مانيتول & \\
\hline
\end{tabular}

در هر ستون تفاوت ميانخينهايى كه حداقل داراى يك حرف مشترى هستند بر اساس آزمون LSD در سطح احتمال بِنج درصد معنى دار نيست.

فتوسنتز و سيستم آنتىاكسيدانى در كياه مىشود(اس). در بررسى

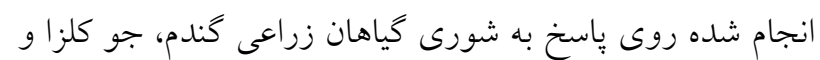

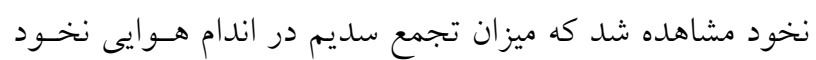

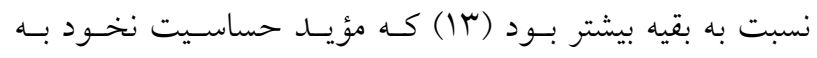

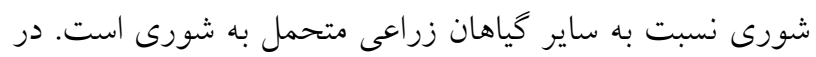

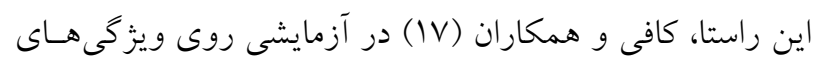

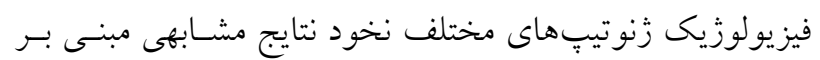

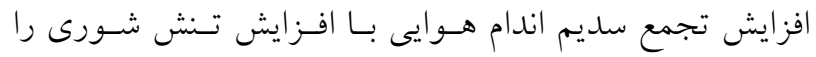
كزارش كردند. علاوهبر ايـن، طباطبايى و احسـانزاده (T9) در

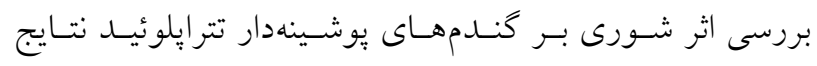
مشابهى مبنى بر افزايش غلظت سديم در شرايط تنش شورى را
با مانيتول و بذرهاى بدون برايمينگ بيشترين ميزان تجمع سديم

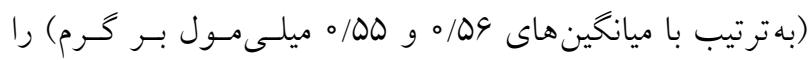

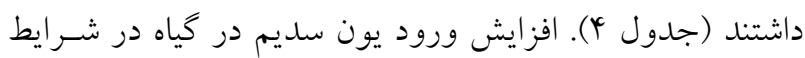
شورى باعث افزايش تجمع يون سديم در سيتويلاسم مسى

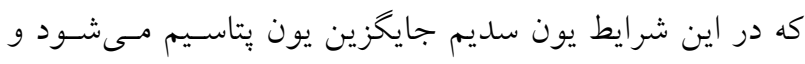

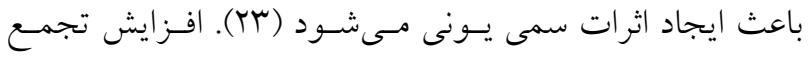

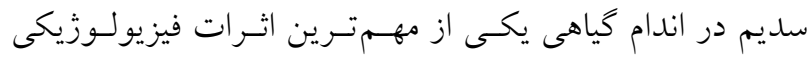
معمول تنش شورى است كه حتى در ارقام متحمـل بـهـ شـورى

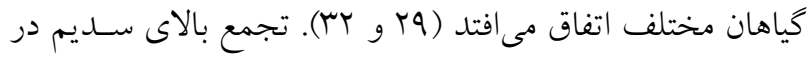
شر ايط تنش شورى بهواسـه افـزايش توليـــ كونـهـــاى فعـال

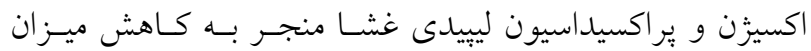




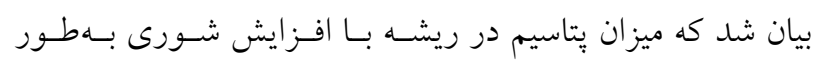
معنى دارى كاهش يافته است.

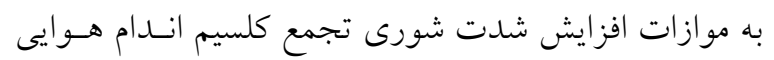

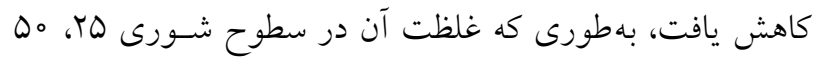

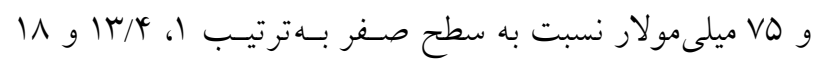

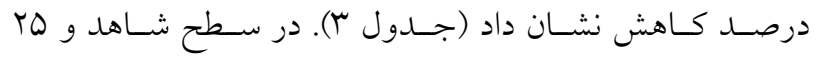
ميلى مولار شورى تفاوتى در بين تيمارهاى مختلف ير ايمينگ از داز

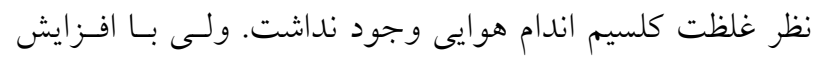

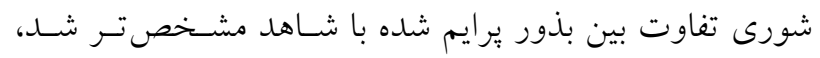

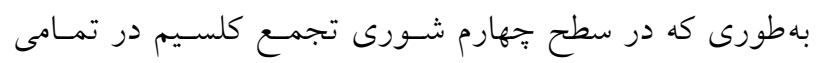

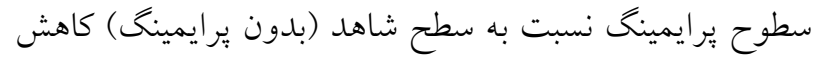

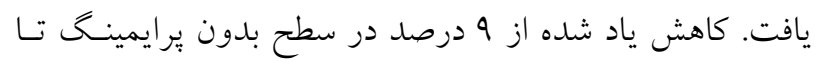

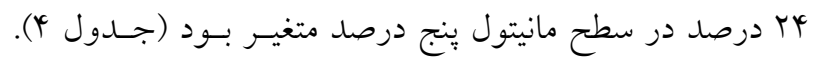

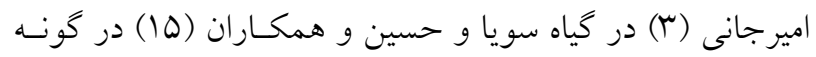

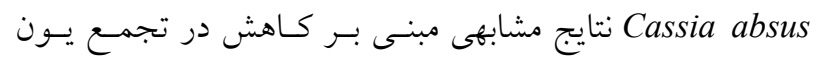
كلسيم به موازات افزايش تنش شورى را كزارش كردند. به موازات افزايش شدت شورى بر نسبت سديم بـهـ يتاسـيم

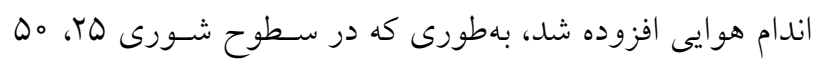

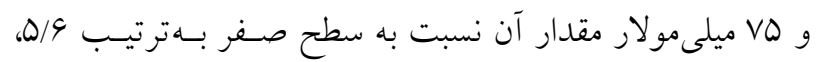

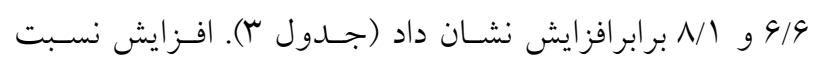

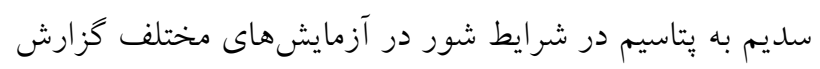

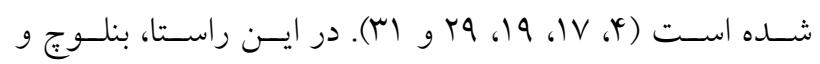
همكاران (Y) در آزمايشى روى اثر شورى بر لوبيا به اين نتيجـهـ

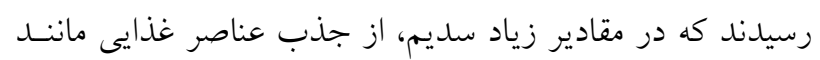

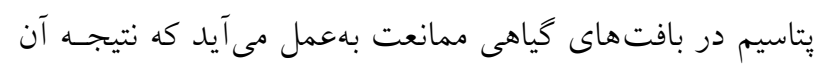

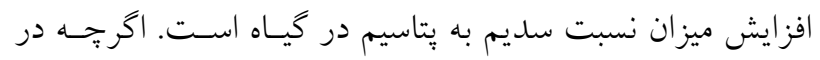

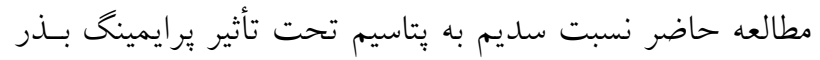
و اثر متقابل آن در شورى قرار نخرفت، اما در مطالعهاى در كياه

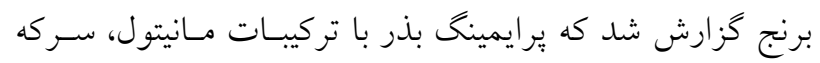

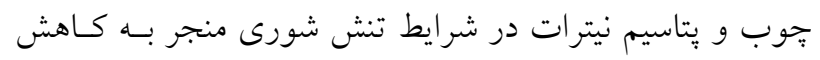

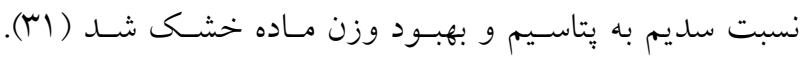

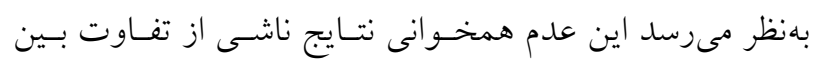

كزارش كردند، همجنين، طبق كزارش اميرجانى (T) بـا افـزايش

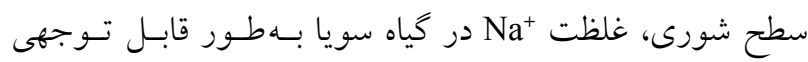
افزايش يافت ولى غلظت نشان داد. مددى ( الب) در آزمايشى كه روى بر ايمينخ سـياهدانه با نانو اكسيد روى و كلسيم در شـرايط شـور انجـام داد بــه ايسن مدئ نتيجه رسيد كه با افزايش شورى بر ميزان تجمع ســـيم افـزوده

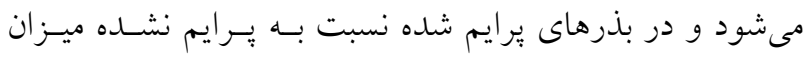

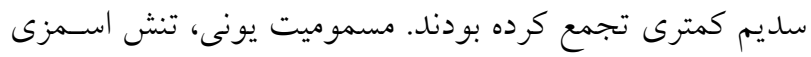

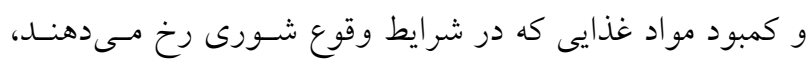

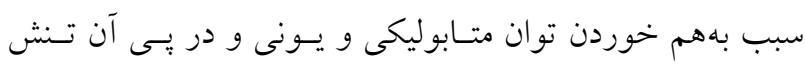

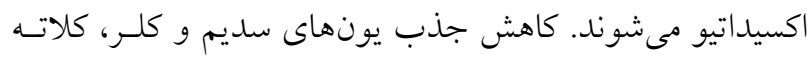

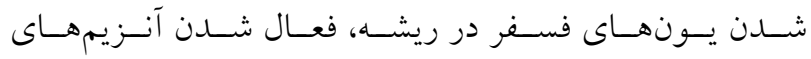

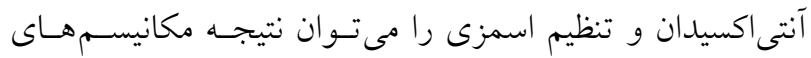

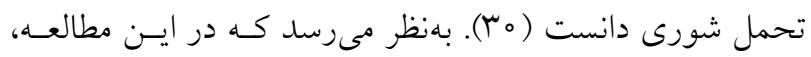

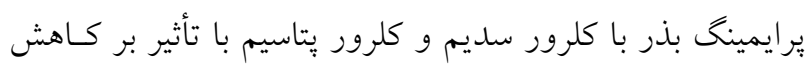

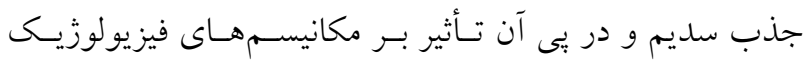

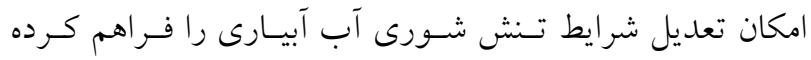
به موازات افزايش شـــت شـورى بــر تجمـع يتاسـيم انــام

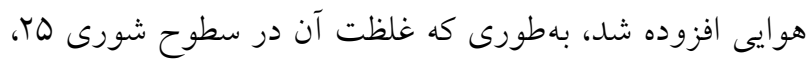

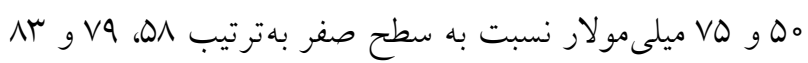

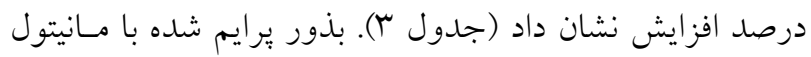

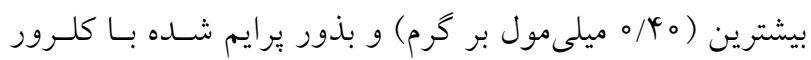

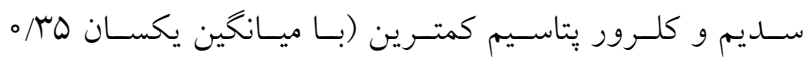

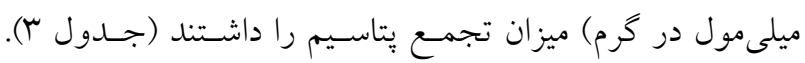

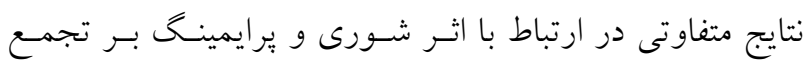

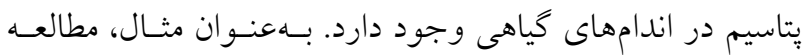

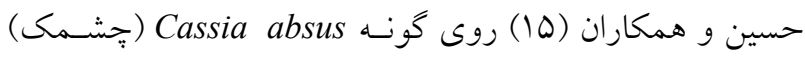
نتايج مشابهى مبنى بر افزايش تجمع بتاسيم با افزايش شـورى را

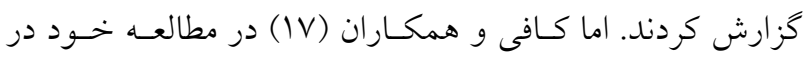

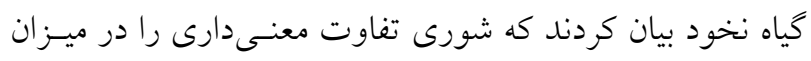
يتاسيم اندامهاى هوايى ايجاد نكــده اسـت. در همـان آزمـايش 
كزارش شده است (9 و (Y). اخر جֶه در مطالعه حاضـر فعاليـت آنزيم آلفا-آميلاز و ميزان يروتئين كل كياهجه اندازه خيرى نشده

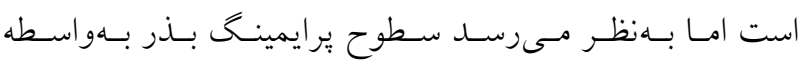
مكانيسمهاى مقاومت به تنش شورى (كاهش جـــب يـونهـاى

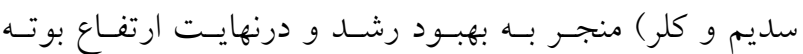

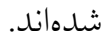

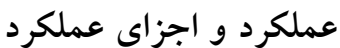

تنش شورى بهطور جشمخيرى تعداد نيام بـارور را كـاهش داد،

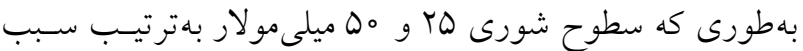

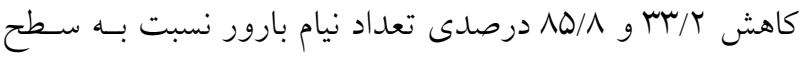
شاهد شدند و سطح جهارم شورى هيج نيام بارورى توليد نكرد (جدول r). بذور يرايم شده با كلرور سديم بيشترين (با ميانخين

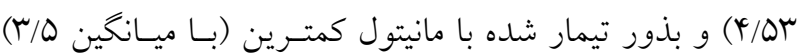

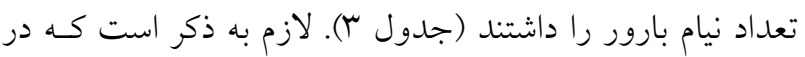
سطح سوم شورى تمام بذورى كه يرايم شده بودند، نيـام بـارور

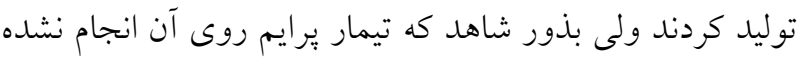

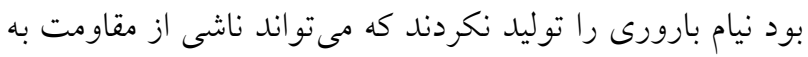

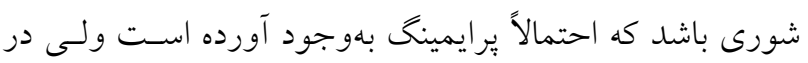

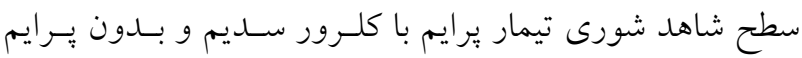

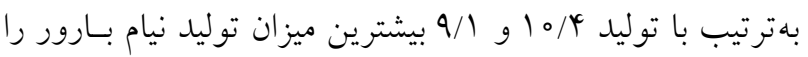
داشتند و اين در حالى است كه در همين سطح تعداد نيام بارور

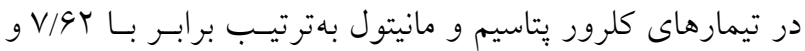

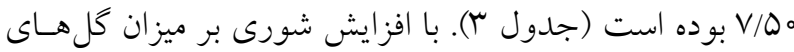

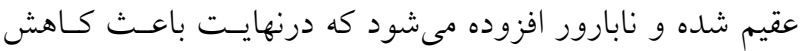
تعداد نيامهاى بارور در كياه مى شود (Tr). عبادى و گلجه كامل

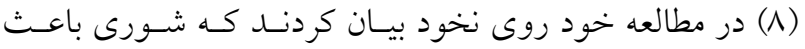
كاهش تعلداد نيام بارور در بوته مىشود و همجنين بيـان كردنـــ كه تيمار هالوير ايمينگ و اسـمويرايمينگ باعـث افـزايش تعـداد

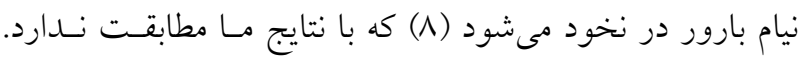

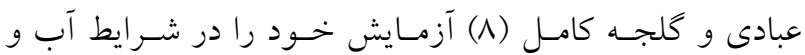

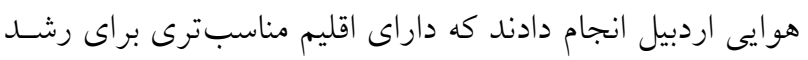

كونــهــاى كيـاهى، غلظـت و نـوع تركيبـاتى اسـت كـهـ بـا آن ير ايمينگ بذر انجام شده است.

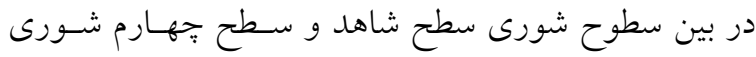

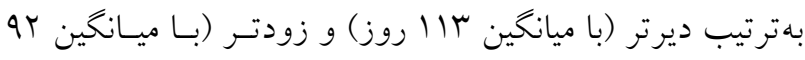

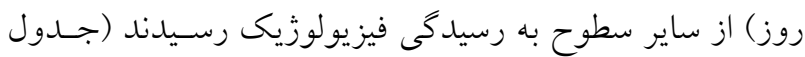

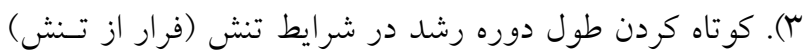
از جمله مكانيسمهاى است كه در بيشتر گياهان زراعى در زمان مو اجه شدن با شرايط تسنش بـهكـار كرفتـه مسىشـود. در تيمـار يرايمينگ، بذور تيمار نشده و بذور تيمار شده با كلـرور يتاسـيم

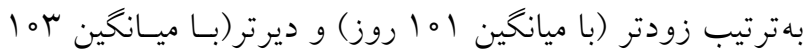
روز) از بقيه سطوح برايم شده به رسيدگى فيزيولوزيك رسيدند (جدول r). هريس و همكاران (I) نشان دادند كـه تيمارهـاى خيساندن نخود در جيبرلين و آب مقطر سبب رسـيدكى زودتسر مىشوند، اخرجه تيمار كردن با كلرور سديم كمترين تأثير را بـر

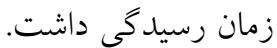

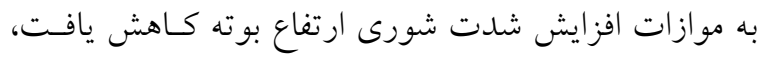

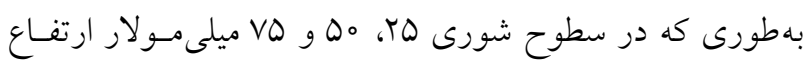

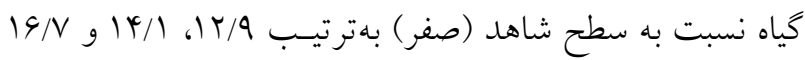

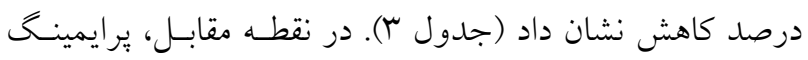

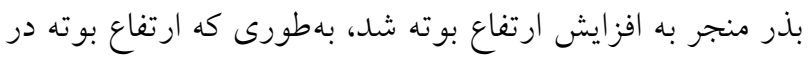

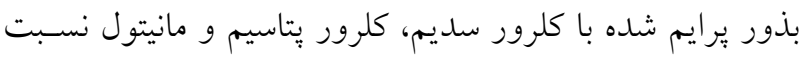

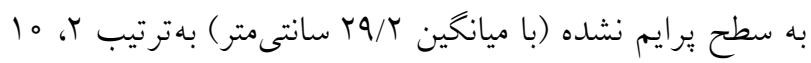
و ץ درصد افزايش نشان دادند (جدول ؟). احمدوند و همكاران

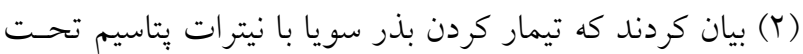
تنش شورى باعث افزايش ارتفاع بوتـه مسىشـود كـه بـا نتـايج

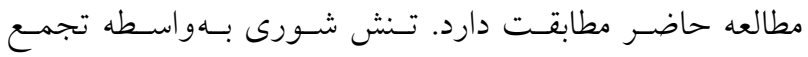
يونهاى سديم و كلر سبب ايجاد تنش آبى در سلولها، ممانعت از فعاليت آنزيمهـا در سيتويلاسـم و كـاهش سـرعت فتوسـتنز

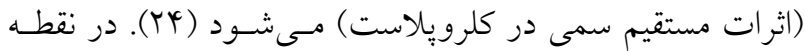
مقابل، اثرات مثبت يرايمينگ بذر بر مكانيسمهاى جوانسهزنسى از

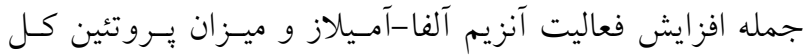
كَاهجه و بهبود رشد كَاهان رشد يافتـه شـرايط تسنش شـورى 


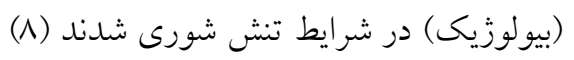

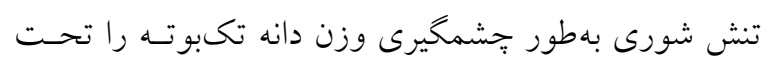

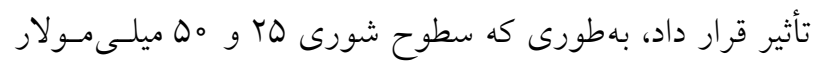

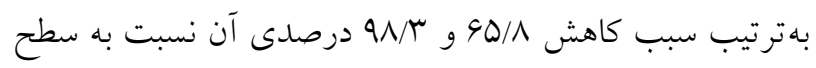

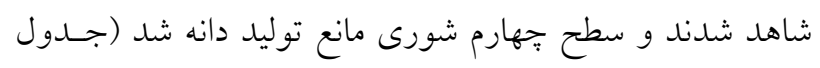

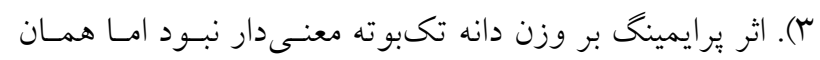

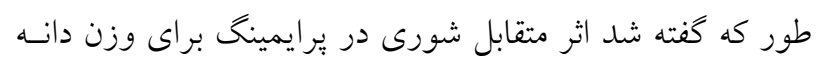

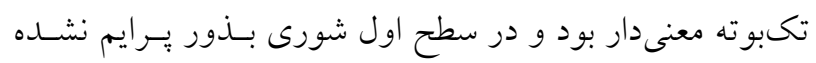

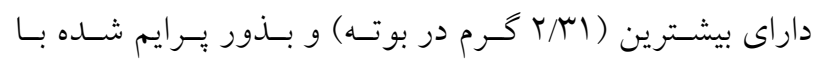

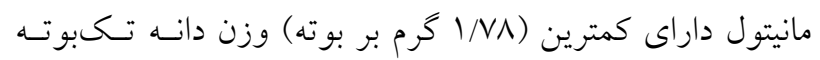

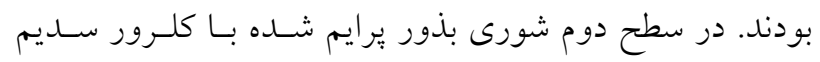

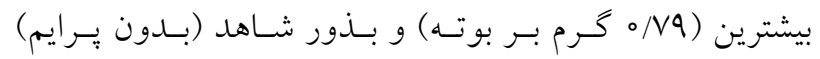

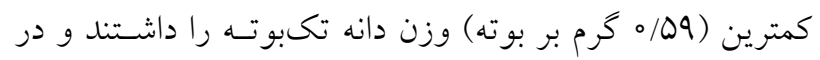

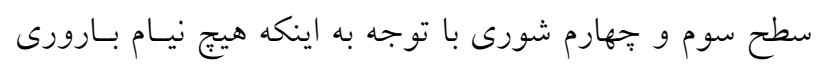

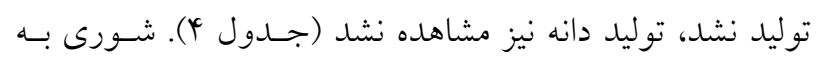

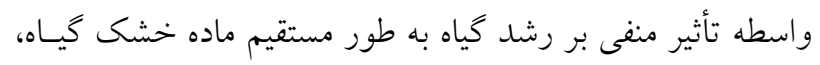

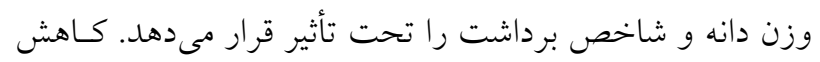

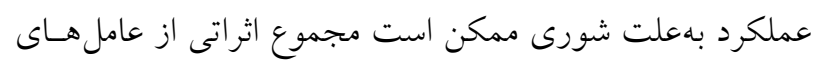

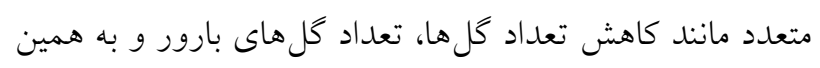

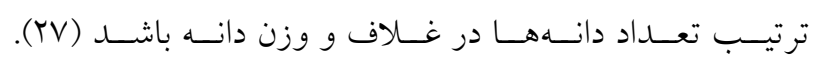

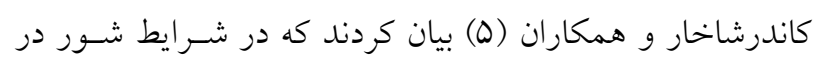

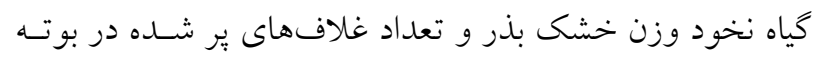

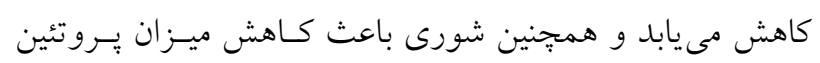
بذر مىشود. در مطالعه حاضر تنش شورى بـهواسـطه بـرهم زدن تعـادل يونى (افزايش نسبت سديم به بتاسيم و كاهش تجمع كلسيم) و در يى آن كاهش در اجزاى عملكرد (ارتفاع بوته، تعداد دانسه در

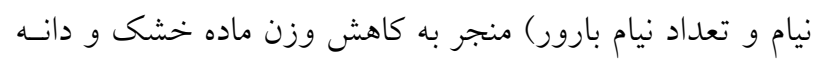

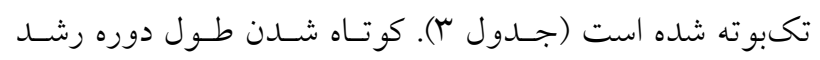

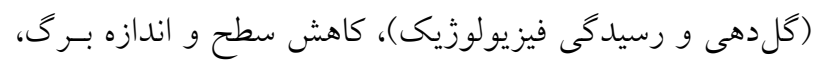

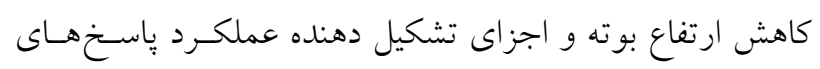

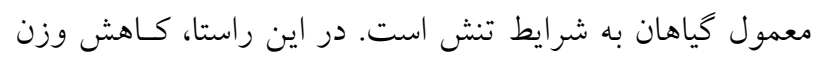

و توليد نخود است ولى اصفهان داراى اقلسيم خشـى و كرمـاى

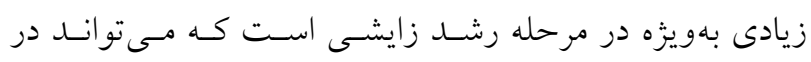

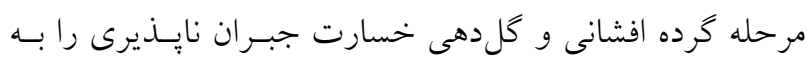
كياه وارد سازد. تنش شورى بهطور معنى دار و قابل تسوجهى تعـداد دانـه در

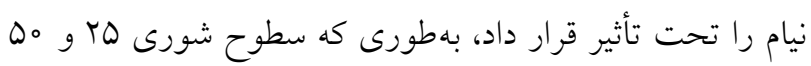

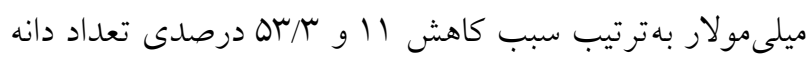

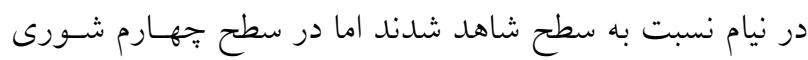

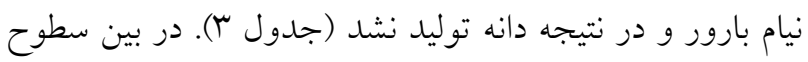

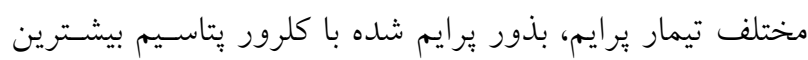

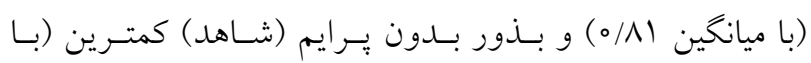

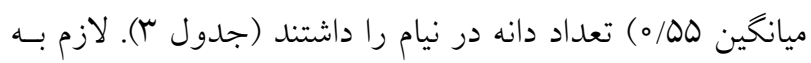
توضيح است كه اين اعداد ميانخين كل سطوح است و در سطح

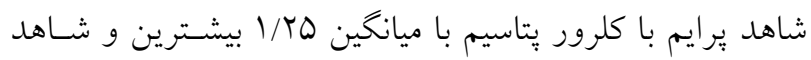

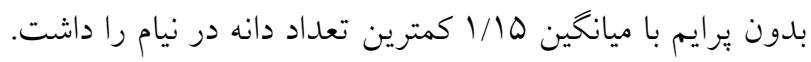

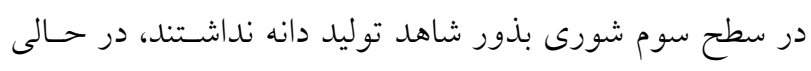

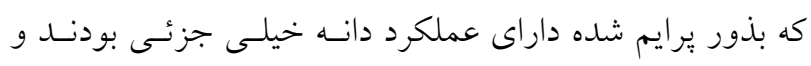

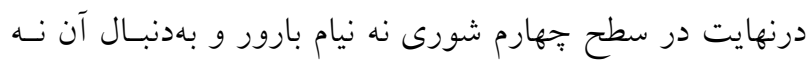

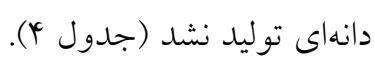

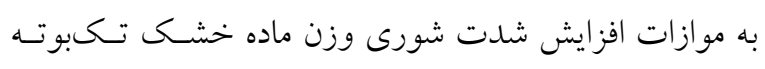

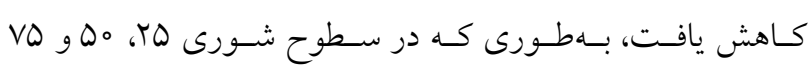

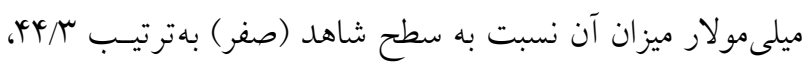

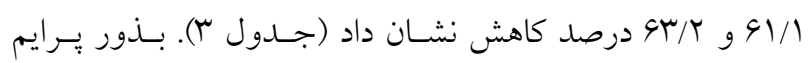

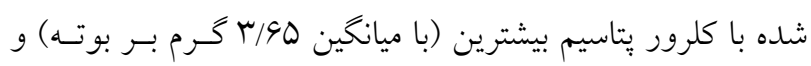

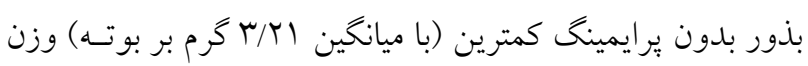

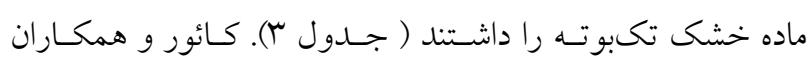

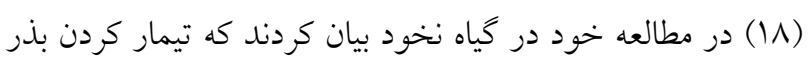

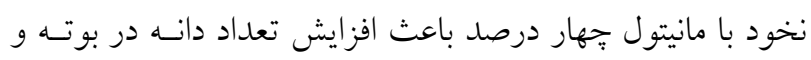

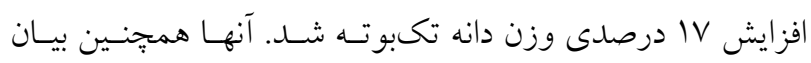
كردند كه برايم كردن بذر باعث افزايش ماده خشك كَياه مىشود.

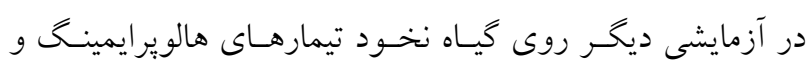

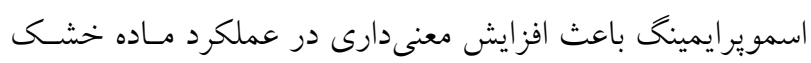


بهترتيب سبب كاهش بـ/N/ و 90/N درصدى آن نسبت به سطح

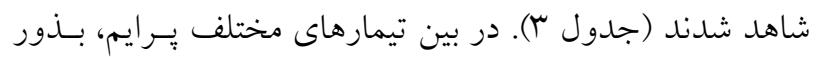

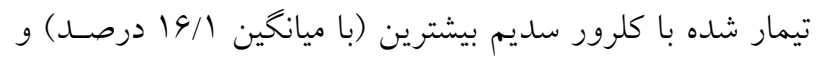

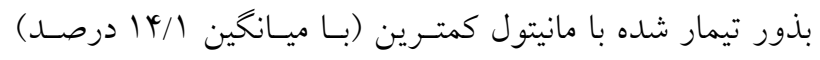

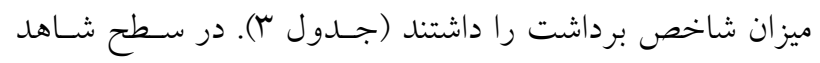

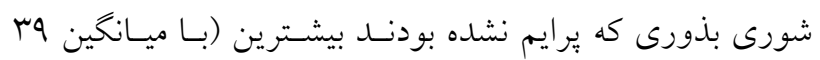

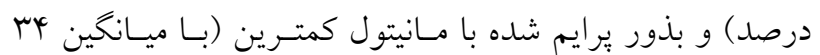

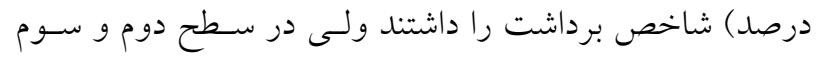
شورى بذور برايم شده شاخص برداشت بيشترى نسبت به بذور

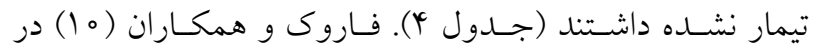
مطالعه خود روى برنج بـه نتـايج مشـابهى دسـت يافتنـد. آنها كزارش كردند كه روشهاى مختلف يرايم كـردن بـــر بـهــور

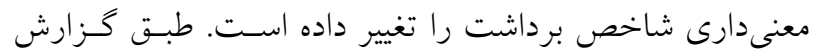
آنها بيشترين شاخص برداشت مربوط به هالوير ايمينخ با كلـرور

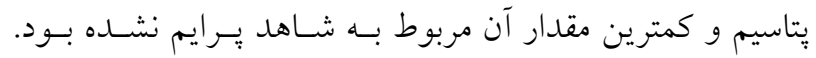
عبادى و كلجه كامل (N) در مطالعه خود روى نخود بيان كردند

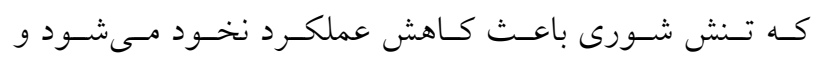

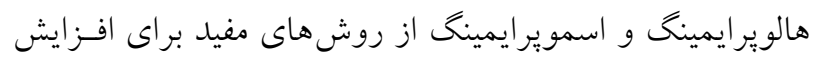
شاخص برداشت در شرايط شور هستند.

\section{نتيجه گيرى}

بر اساس يافته هاى مطالعه حاضر مىتـوان بيـان داشـت كـه بـهـ

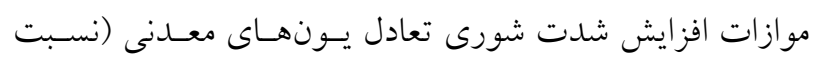

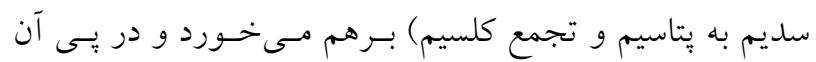
مراحل رشدى و فنولوزيكى، عملكرد و اجراى عملكرد حتى در لهر

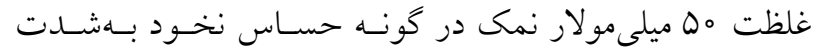

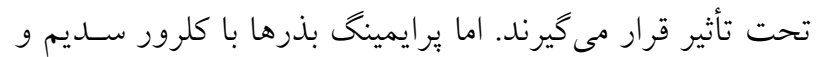

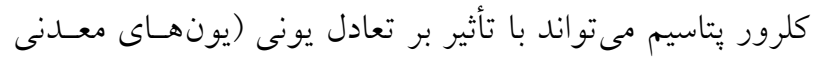

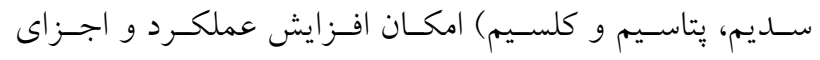

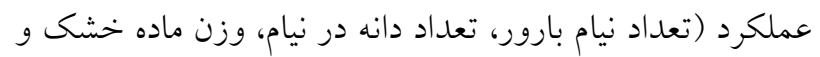

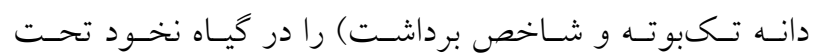
غلظتهاى متوسط نمك آب آبيارى فراهم كند.

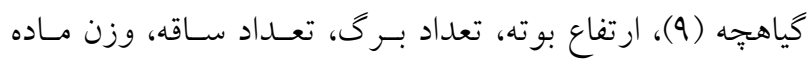

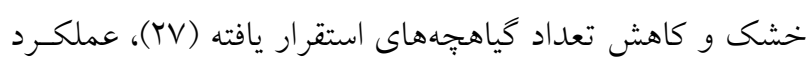

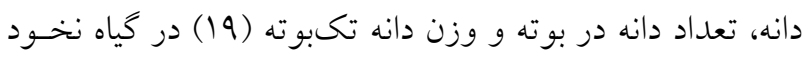

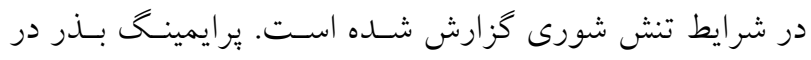

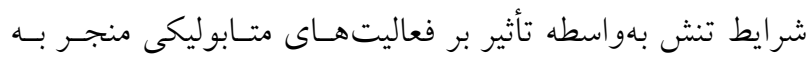

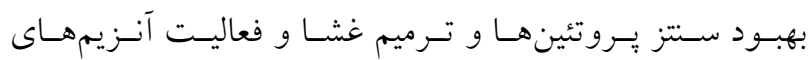

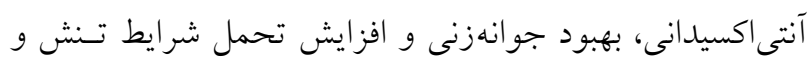
در نهايت بهبود عملكرد مىشود (Yr). ضرايب همبستكى سـاده

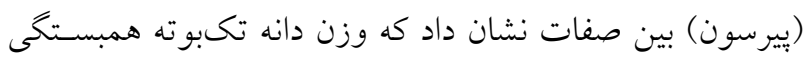
مثبت و معنى دار بــا اجـزاى عملكـــد شـامل تعــاد نيـام بـارور

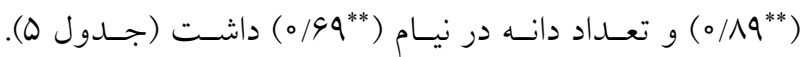

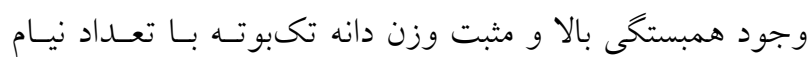
بارور دلالت بر اين امر دارد كه تعداد نيام بارور مهمترين صفت

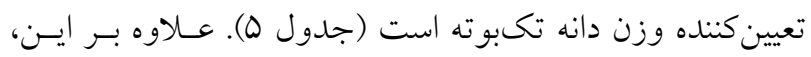

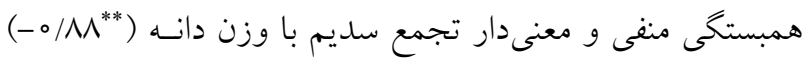

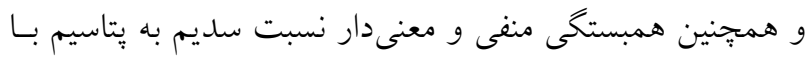

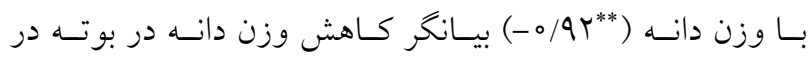

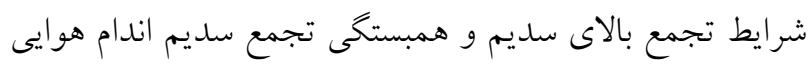

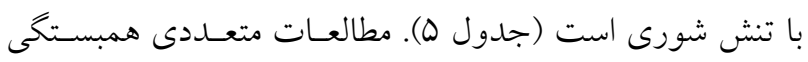

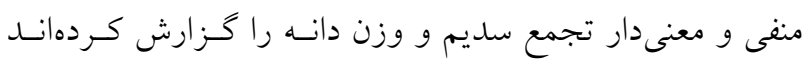
(Yq و r Tr). احمدوند و همكاران (Y) بيان كردند كه تيمار كردن

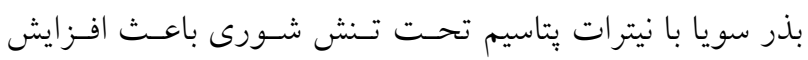
ارتفاع، وزن خشك، شاخص سطح برى و عملكرد دانه مىشود.

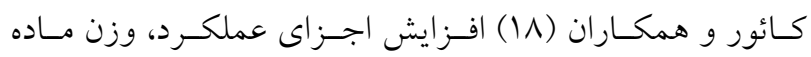

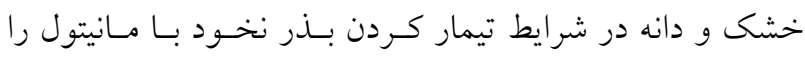
كزارش كردند. عبادى و كلجه كامل (N) افزايش عملكـــد دانـه نخود در شرايط شورى را با تيمار بذور بـا سـه تركيـب كلــرور

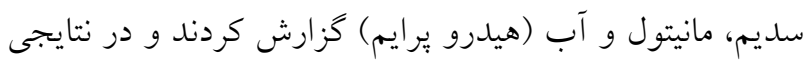
مشابه بيان داشتند كه بيشتيمار كلرور سديم نقـش بسـزئى در

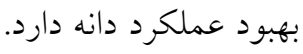
تنش شورى بهطور خشمخيرى شاخص برداشـت را تحــت

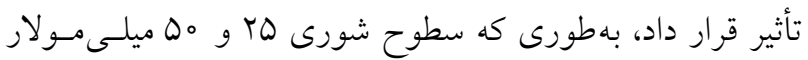




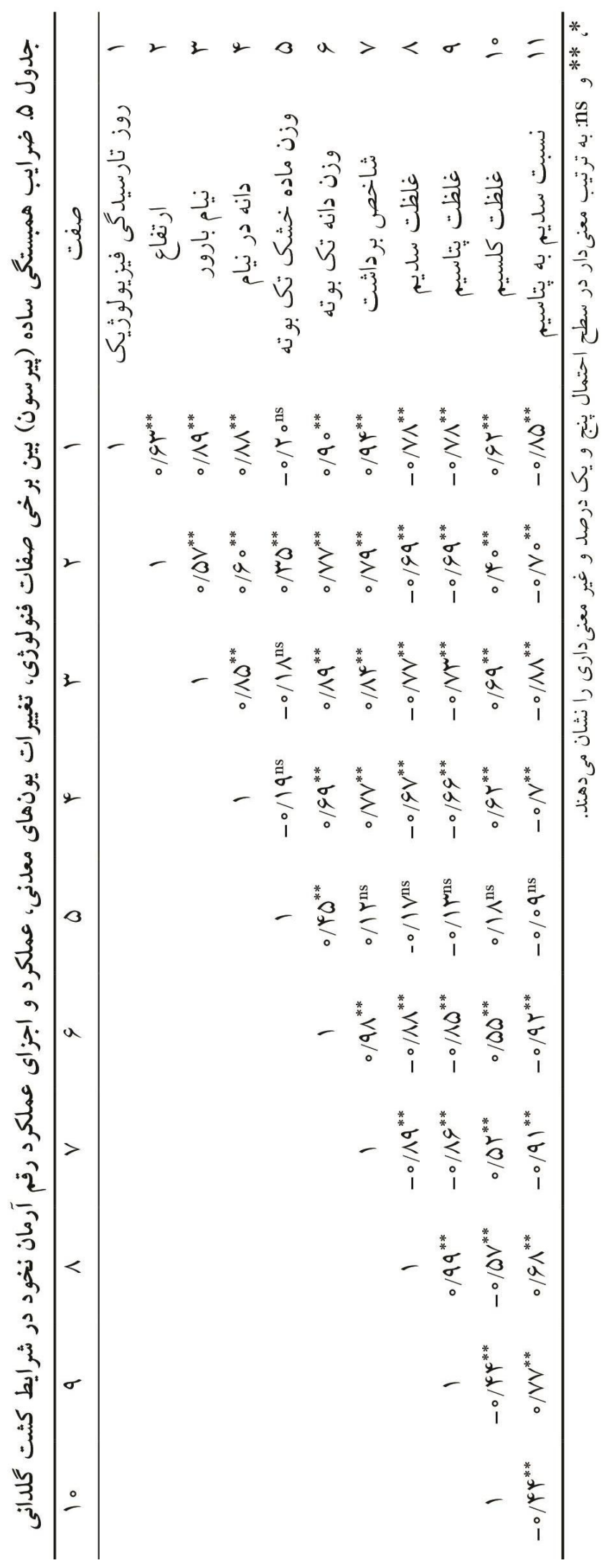




$$
\text { توسط مركز تحقيقات ديسم سـرارود اسـتان كرمانشـاه تشـكر و }
$$

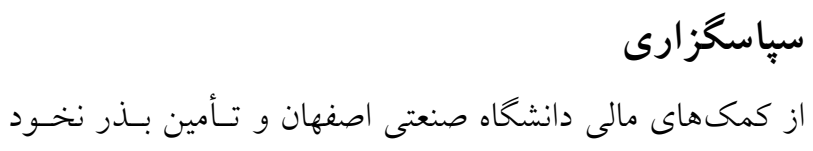

منابع مورد استفاده

1. Acosta-Motos, J., M. Ortuño, A. Bernal-Vicente, P. Diaz-Vivancos, M. Sanchez-Blanco and J. Hernandez. 2017. Plant responses to salt stress: adaptive mechanisms. Agronomy 7(1): 1-38.

2. Ahmadvand, G., F. Soleimani and M. Pouya. 2012. Effect of seed priming with potassium nitrate on germination and emergence traits of two soybean cultivars under salinity stress conditions. American-Eurasian Journal of Agricultural \& Environmental Sciences 12: 769-774.

3. Amirjani, M. R. 2010. Effect of salinity stress on growth, mineral composition, proline content, antioxidant enzymes of soybean. American Journal of Plant Physiology 5: 350-360.

4. Benlloch, M., M. A. Ojeda, J. Ramos and A. Rodriguez-Navarro. 1994. Salt sensitivity and low discrimination potassium and sodium in bean plant. Plant and Soil 43: 1076-1090.

5. Chandarashekhar, V., R. Murumkar and D. C. Chavan. 1986. Influence of salt stress on biochemical processer in chickpea (Cicer aretinum L.). Plant and Soil 96: 439-443.

6. Chen, K. and R. Arora. 2013. Priming memory invokes seed stress-tolerance. Environmental and Experimental Botany 94: 33-45.

7. Duman, I. 2006. Effect of seed priming with $\mathrm{PEG}$ and $\mathrm{K}_{3} \mathrm{PO}_{4}$ on germination and seedling growth in lettuce. Journal of Biological Sciences 9: 923-928.

8. Ebadi A. and S. Gollojeh Kamel. 2009. Effect of seed priming on growth and yield of chickpea under saline soil. Recent Research in Science and Technology 1: 282-286.

9. Ebtihal, M. E., S. S. Mervat and M. M. Tawfik. 2018. Glutathione treatment alleviate salinity adverse effects on growth, some biochemical aspects, yield quantity and nutritional value of chickpea plant. SciFed Journal of Global Warming 2(2): 1-11.

10. Farooq, M., M. A. Shahzand and A. W. Basra. 2006. Priming of field-sown rice seed enhance germination, seedling establishment, allometry and yield. Plant Growth Regulation 49: 285-294.

11. Ghassemi-Golezani, K., A. A. Aliloo, M. Valizadeh and M. Moghaddam. 2008. Effects of hydro and osmo-priming on seed germination and field emergence of Lentil (Lens culinari Medik.). Notulae Botanicae Horti Agrobotanici Cluj-Napoca 36: 29-33.

12. Harris, D., A. Joshi, P. A. Khan, P. Gothkar and P. S. Sodhi. 1999. On-farm seed priming in semi-arid agriculture: development and evaluation in corn, rice and chickpea in India using participatory methods. Experimental Agriculture 35: 15-29.

13. Harsharn, S. G. 2010. Water uptake, water use efficiency, plant growth and ionic balance of wheat, barley, canola and chickpea plants on a sodic vertosol with variable subsoil $\mathrm{NaCl}$ salinity. Agricultural Water Management 97: 148-156.

14. Hu, Y. and U. Schmidhalter. 2005. Drought and salinity: A comparison of their effects on the mineral nutrition of plants. Journal of Plant Nutrition and Soil Science 168: 541-549.

15. Hussain, K. H., A. Majeed and M. Farrukh-Nisar. 2009. Growth and ionic adjustments of Chaksu (Cassia absus L.) under $\mathrm{NaCl}$ stress. Journal of Agriculture and Environmental Sciences 6: 557-560.

16. Hussain, M., M. Farooq, S. M. A. Basra and N. Ahmad. 2006. Influence of seed priming techniques on the seedling establishment, yield and quality of hybrid sunflower. International Journal of Agriculture and Biology 8: 14-18.

17. Kafi, M., A. Bagheri, J. Nabati, M. Zare-Mehrjerdi and A. Masomi. 2011. Effect of salinity on some physiological variables of 11 chickpea genotypes under hydroponic conditions. Journal of Science and Technology of Greenhouse Culture 1(4): 55-70. (In Farsi).

18. Kaur, S. A., K. Gupta and N. Kaur. 2005. Seed priming increases crop yield possibly by modulating enzymes of sucrose metabolism in chickpea. Journal of Agronomy and Crop Science 191: 81-87.

19. Khani-Karimabadi, Y., A. Gholami Zali, P. Ehsanzadeh and J. Razmjoo. 2018. Modification of some mineral ionic compositions, phenology and yield of pot-grown chickpea as affected by saline water. Plant Process and Function 23(7): 111-123. (In Farsi).

20. Khodabakhsh, F., R. Amooaghaie, A, Mostajeran and G. Emtiazi. 2010. Effect of hydro and osmopriming in two commercial chickpea cultivars on germination, growth parameters and nodules number in salt stress condition. Journal of Plant Biology 6(2): 71-86. (In Farsi). 
21. Madadi, M. 2013. Effect of black cumin seed priming with calcium nitrate and nano-zinc oxide on germinability and seedling growth under salinity stress. MSc. Thesis. University of Mohaghegh Ardabili. Ardabil, Iran. (In Farsi).

22. McDonald, M. B. 1999. Seed deterioration: physiology, repair and assessment. Seed Science and Technology 27: 177-237.

23. Munns, R. 2002. Comparative physiology of salt and water stress. Plant, Cell \& Environment 25: 239-250.

24. Munns, R. and M. Tester. 2008. Mechanisms of salinity tolerance. Annual Review of Plant Biology 59: 651-681.

25. Page, A. L., R. A. Miller and D. R. Keeny. 1982. Methods of soil analysis. II. Chemical and Microbiological Properties, $2^{\text {nd }}$ ed., ASA, SSSA, Madison, Wisconsin USA.

26. Sadak-Mervat, Sh, E. M. Abd Elhamid and H. A. Mostafa. 2013. Alleviation of adverse effects of salt stress in wheat cultivars by foliar treatment with antioxidants I. Changes in growth, some biochemical aspects and yield quantity and quality. American-Eurasian Journal of Agricultural \& Environmental Sciences 13: 1476-1487.

27. Singla, R. and N. Garg. 2005. Influence of salinity on growth and yield attributes in chickpea cultivars. Turkish Journal of Agriculture and Forestry 29: 231-235.

28. Sivritepe, N., H. O. Sivritepe and A. Eris. 2003. The effect of $\mathrm{NaCl}$ priming on salt tolerant in melon seedling grown under condition. Scientia Horticulturae 97: 229-237.

29. Tabatabaei, S. and P. Ehsanzadeh, 2016. Photosynthetic pigments, ionic and antioxidative behaviour of hulled tetraploid wheat in response to NaCl. Photosynthetica 54(3): 340-350.

30. Taize, L. and E. Zeiger, 1998. Plant Physiology. $2^{\text {nd }}$ Ed., Sinauar Associates Publishers, Sunderland, Massachusetts.

31. Theerakulpisut, P., N. Kanawapee, and B. Panwong. 2017. Seed priming alleviated salt stress effects on rice seedlings by improving $\mathrm{Na}^{+} / \mathrm{K}^{+}$and maintaining membrane integrity. International Journal of Plant Biology 7(1): 53-58.

32. Turner, N. C., T. D. Colmer, J. Quealy, R. Pushpavalli, L. Krishnamurthy, J. Kaur, G. Singh, K. H. M., Siddique and V. Vadez. 2013. Salinity tolerance and ion accumulation in chickpea (Cicer arietinum L.) subjected to salt stress. Plant and Soil 365: 347-361. 


\title{
Mitigating Effect of Seed Priming on Salt-Associated Alterations in Morphological Traits, Inorganic lons, Yield and Yield Components of Chickpea (Cultivar Arman)
}

\author{
A. Gholami Zali ${ }^{1}$, Y. Khani KarimAbadi ${ }^{1}$, P. Ehsanzade ${ }^{2^{*}}$ and J. Razmjoo ${ }^{2}$
}

(Received: January 27-2019; Accepted: April 29-2019)

\begin{abstract}
In order to unravel the potential mitigating effects of seed priming on salt-stressed chickpea (Cicer arietinum), a 4-replicate factorial out-door completely random design pot experiment was conducted on Arman cultivar of chickpea at the research field of the Isfahan University of Technology, Isfahan (Latitude of $32^{\circ} 38^{\prime}$ North, Longitude of $51^{\circ} 39^{\prime}$ East, and an Altitude of $1620 \mathrm{~m}$ above sea level), Iran. Irrigation water salinity at four levels $(0,25,50$, and $75 \mathrm{mM}$ $\mathrm{NaCl})$ and seed priming at four levels, including control (non-priming), priming with mannitol (5\%), $\mathrm{NaCl}(0.5 \%)$ and $\mathrm{KCl}(0.5 \%)$ were tested. $\mathrm{Na}^{+}$and $\mathrm{K}^{+}$concentrations and $\mathrm{Na}^{+} / \mathrm{K}^{+}$were increased, but $\mathrm{Ca}^{+2}$ concentration, days to physiological maturity, seed yield, fertile pods/plant, seeds/pod, above-ground dry mass, and harvest index were decreased with aggravation of salinity. Chickpea seed priming by $\mathrm{NaCl}$ and $\mathrm{KCl}$ led to increase in yield components and hence seed yield of the salt-stricken plants, compared to non-primed and mannitol-primed plants due, seemingly, to decrease in tissue $\mathrm{Na}^{+}$concentration. Albeit, priming-associated modifications in $\mathrm{Na}^{+}$and $\mathrm{Ca}^{+2}$ concentrations, fertile pods/plant, seeds/pod, seed yield, and harvest index varied with the level of salinity. In contrary to the non-primed chickpea, plants receiving priming were able to produce fertile pods, due perhaps to the mitigative effects of the priming on salt-stricken plants. All results, taken together, confirm that the salt-sensitive legume chickpea may be harmed by $50 \mathrm{mM}$ salinity of irrigation water but seed priming by $\mathrm{NaCl}$ and $\mathrm{KCl}$ may suppress the harmful effects.
\end{abstract}

Keywords: Halopriming $(\mathrm{NaCl}$ and $\mathrm{KCl})$ Osmopriming (mannitol), Seed weight/plant

1, 2. MSc. Students and Professors, Respectively, Department of Agronomy and Plant Breeding, College of Agriculture, Isfahan University of Technology, Isfahan, Iran.

*: Corresponding Author, Email: ehsanzadehp@gmail.com 